\title{
Evidence for Differential Cortical Input to Direct Pathway versus Indirect Pathway Striatal Projection Neurons in Rats
}

\author{
Wanlong Lei, Yun Jiao, Nobel Del Mar, and Anton Reiner \\ Department of Anatomy and Neurobiology, College of Medicine, The University of Tennessee Health Science Center, Memphis, Tennessee 38163
}

The two main types of corticostriatal neurons are those that project only intratelencephalically (IT-type), the intrastriatal terminals of which are $0.41 \mu \mathrm{m}$ in mean diameter, and those that send their main axon into pyramidal tract and have a collateral projection to striatum (PT-type), the intrastriatal terminals of which are $0.82 \mu \mathrm{m}$ in mean diameter. We used three approaches to examine whether the two striatal projection neuron types (striatonigral direct pathway vs striatopallidal indirect pathway) differ in their input from IT-type and PT-type neurons. First, we retrogradely labeled one striatal projection neuron type or the other with biotinylated dextran amine (BDA)3000 molecular weight. We found that terminals making asymmetric axospinous contact with striatonigral neurons were $0.43 \mu \mathrm{m}$ in mean diameter, whereas those making asymmetric axospinous contact with striatopallidal neurons were $0.69 \mu \mathrm{m}$. Second, we preferentially immunolabeled striatonigral neurons for $\mathrm{D}_{1}$ dopamine receptors or striatopallidal neurons for $\mathrm{D}_{2}$ dopamine receptors and found that axospinous terminals had a smaller mean size $(0.45 \mu \mathrm{m})$ on $\mathrm{D}_{1}+$ spines than on $\mathrm{D}_{2}+$ spines $(0.61 \mu \mathrm{m})$. Finally, we combined selective BDA labeling of IT-type or PT-type terminals with immunolabeling for $\mathrm{D}_{1}$ or $\mathrm{D}_{2}$, and found that IT-type terminals were twice as common as PT-type on $\mathrm{D}_{1}+$ spines, whereas PT-type terminals were four times as common as IT-type on $\mathrm{D}_{2}+$ spines. These various results suggest that striatonigral neurons preferentially receive input from IT-type cortical neurons, whereas striatopallidal neurons receive greater input from PT-type cortical neurons. This differential cortical connectivity may further the roles of the direct and indirect pathways in promoting desired movements and suppressing unwanted movements, respectively.

Key words: basal ganglia; cortex; corticostriatal; direct pathway; indirect pathway; striatum

\section{Introduction}

The cerebral cortex gives rise to a massive excitatory glutamatergic projection that provides the striatum with the information it needs for its role in motor control (Gerfen, 1992; Wilson, 1992). This input primarily ends as terminals that make asymmetric synaptic contact with dendritic spines of striatal projection neurons, which make up $95 \%$ of striatal neurons (Albin et al., 1989; Reiner and Anderson, 1990; Gerfen, 1992). In each cortical region, two types of corticostriatal neuron can be distinguished (Wilson, 1987; Cowan and Wilson, 1994; Wright et al., 1999, 2001; Reiner et al., 2003). One type, which we refer to as the pyramidal tract (PT)-type, possesses 15-20 $\mu$ m perikarya found primarily in lower layer $\mathrm{V}$, and their striatal projection arises as a collateral of the main axon as it traverses striatum in its course to the ipsilateral pyramidal tract (Wilson, 1987; Cowan and Wilson, 1994; Levesque et al., 1996a,b; Levesque and Parent, 1998; Reiner et al., 2003). The second type projects to basal ganglia and cortex

Received May 21, 2004; revised Aug. 11, 2004; accepted Aug. 11, 2004.

This research was supported by NS-19620 and NS-28721 (A.R.) and The University of Tennessee Center for Excellence in Neuroscience (Y.J.). We thank Drs. C. Meade, Y.P. Deng, and Z. Sun for their helpful comments during the course of this study, and we are grateful to J.C. Lopez, S.L. Cuthbertson, Kathy Troughton, Raven Babcock, Amanda Valencia, Toya Kimble, and Yunping Deng for technical assistance and advice.

Correspondence should be addressed to Dr. Anton Reiner, Department of Anatomy and Neurobiology, The University of Tennessee Health Science Center, 855 Monroe Avenue, Memphis, TN 38163. E-mail: areiner@utmem.edu.

Y. Jiao's present address: Department of Developmental Neurobiology, Saint Jude Children's Research Hospital, 332 North Lauderdale, Memphis, TN 38105.

DOI:10.1523/JNEUROSCI.1990-04.2004

Copyright $\odot 2004$ Society for Neuroscience $\quad$ 0270-6474/04/248289-11\$15.00/0 but not outside telencephalon. These neurons, which we refer to as the intratelencephalically projecting (IT)-type, possess $12-15$ $\mu \mathrm{m}$ perikarya found mainly in layer III and upper layer V (Landry et al., 1984; Wilson, 1987; Cowan and Wilson, 1994; Levesque et al., 1996a,b; Levesque and Parent, 1998; Wright et al., 1999, 2001; Reiner et al., 2003).

PT-type neurons give rise to focal clusters of fine processes and terminals (each cluster being $\sim 250 \mu \mathrm{m}$ in diameter) scattered in striatum over a 1-2 mm region (Cowan and Wilson, 1994). The PT input to striatum has attracted interest because it may provide striatum with a copy of the cortical motor signal transmitted to brainstem and spinal cord (Landry et al., 1984; Levesque et al., 1996a,b). IT-type neurons project to ipsilateral striatum, as well as contralateral in many cases, and have a uniform intrastriatal arborization with sparse en passant terminals over a $1.5 \mathrm{~mm}$ expanse (Wilson, 1987; Cowan and Wilson, 1994; Wright et al., 1999, 2001). Previously (Reiner et al., 2003), we noted that axospinous PT-type terminals in rat striatum are typically large $(0.82 \mu \mathrm{m}$ in mean diameter) and irregular in shape, whereas axospinous IT-type terminals are characteristically small (average diameter of $0.41 \mu \mathrm{m}$ ) and regular in shape (round or oval). Wright et al. $(1999,2001)$ reported similar findings.

Consistent with the morphological differences between them, IT-type and PT-type corticostriatal neurons carry different signals, with PT-type neurons, but not IT-type neurons, showing movement-related activity (Turner and DeLong, 2000; Beloozerova et al., 2003). To understand better how cortical input to the 
striatum participates in the role of the basal ganglia in movement control, it is important to know whether the two types of corticostriatal neurons project differentially to the two main types of striatal projection neurons, those of the direct pathway and those of the indirect pathway (Albin et al., 1989; DeLong, 1990). To this end, we preferentially labeled one or the other of these two striatal projection neuron types by retrograde labeling or dopamine receptor immunolabeling and examined the size of the axospinous terminals on their dendrites. Additionally, we preferentially labeled one or the other striatal projection neuron type by dopamine receptor immunolabeling in tissue in which either PT-type or IT-type input had been selectively labeled with biotinylated dextran amine (BDA) (Reiner et al., 2003). Our findings indicate that PT-type terminals preferentially contact indirect pathway striatal neurons, whereas IT-type terminals preferentially contact direct pathway neurons. These findings suggest that PT-type corticostriatal neurons may provide indirect pathway neurons with information about ongoing movements needed for their role in suppressing unwanted movements, whereas integration of ITtype input from diverse cortical areas may underlie the role of direct pathway neurons in promoting desired movements.

\section{Materials and Methods}

Animals and experimental plan. Results from 25 adult male Sprague Dawley rats (Harlan, Indianapolis, IN) are presented here. Efforts were made to minimize animal suffering and use as few animals as possible, and all animal use was performed in accordance with the National Institutes of Health Guide for Care and Use of Laboratory Animals, Society for Neuroscience Guidelines, and University of Tennessee Health Science Center Guidelines.

In the first set of studies, we characterized the size of terminals making asymmetric axospinous contact with striatal neurons projecting to the globus pallidus (GP) [the homolog of the primate external segment of globus pallidus (GPe)], that is, indirect pathway striatal neurons (Albin et al., 1989; DeLong, 1990), compared with those making asymmetric axospinous contact with striatal neurons projecting to the substantia nigra (SN) and/or the entopeduncular nucleus (EP) [the homolog of the primate internal segment of globus pallidus (GPi)], that is, direct pathway striatal neurons (Albin et al., 1989; DeLong, 1990). In three rats, the retrograde tracer BDA3k [dextran, biotinylated, 3000 molecular weight (MW), anionic, lysine fixable; Molecular Probes, Eugene, OR] was injected bilaterally into GP, and in four rats BDA3k was injected bilaterally into the SN. The injection site in representative cases of each injection type is shown (see Fig. 1). Injection of retrograde tracer into GP predominantly labels striato-GP neurons (which are enkephalinergic), as well as some striatonigral and striato-EP neurons [which characteristically contain substance P (SP)] because of their slight collateralization within the GP (Kawaguchi et al., 1990; Reiner and Anderson, 1990; Wu et al., 2000; Wang et al., 2002). Injections of retrograde tracer into substantia nigra labels direct pathway striatal neurons projecting to substantia nigra, which include neurons projecting to both EP and substantia nigra pars reticulata $(\mathrm{SNr}$ ) and neurons projecting to $\mathrm{SNr}$ but not $\mathrm{EP}$ (Kawaguchi et al., 1990; Reiner and Anderson, 1990; Gerfen, 1992; Wu et al., 2000). For simplicity, we will commonly refer to both types of direct pathway striatal neurons as striatonigral, because both project to nigra in rodents. Injections of retrograde tracer into the substantia nigra do not label striato-GP neurons, because these neurons do not send a collateral to nigra (Kawaguchi et al., 1990; Wu et al., 2000; Wang et al., 2002). We analyzed by electron microscopy (EM) the size and shape of terminals making asymmetric axospinous synaptic contact on spine heads of the retrogradely labeled striato-GP and striatonigral neurons in the dorsolateral somatomotor sector of the striatum. The size of terminals was determined by measuring them at their widest diameter parallel to the postsynaptic density, and spines were identifiable by their size, continuity with dendrites, prominent postsynaptic density, and/or the presence of spine apparatus (Wilson et al., 1983). We focused our attention on dorsolateral striatum so as to minimize inclusion of striosomal neurons, which project to pars compacta of the nigra (Gerfen, 1992) and are scarce in dorsolateral striatum (Gerfen, 1992; Desban et al., 1993), among the striatonigral neurons analyzed. Thus, in the analyzed sample of retrogradely labeled neurons projecting to nigra, striato-SNr neurons are likely to have been the most abundant, because they are approximately twice as common as striato-EP neurons in rats (Kawaguchi et al., 1990; Wu et al., 2000). For GP injections, by only analyzing labeled neurons in dorsolateral striatum, we were also able to avoid any neurons incidentally labeled by passage of the syringe through medial striatum in its course to GP.

In our second set of studies, we sought also to characterize the size of the terminals making axospinous contact with striato-GP neurons compared with those making axospinous contact with striatonigral neurons. In this set of studies, we relied on the finding that striato-GP neurons are enriched in $\mathrm{D}_{2}$ receptors but poor in $\mathrm{D}_{1}$ receptors, whereas striatonigral neurons are enriched in $\mathrm{D}_{1}$ receptors but poor in $\mathrm{D}_{2}$ receptors (Gerfen et al., 1990; Le Moine and Bloch, 1995). We used $D_{1}$ immunolabeling as an alternative way of preferentially labeling striatonigral direct pathway neurons, therefore, and $\mathrm{D}_{2}$ immunolabeling as an alternative means for preferentially labeling indirect pathway striato-GP neurons. Included among the neurons immunolabeled for $\mathrm{D}_{1}$ are those projecting primarily to the nigra, as well as those projecting both to EP and nigra (Parent et al., 1989, 1995; Kawaguchi et al., 1990; Hersch et al., 1995; Wu et al., 2000). We analyzed by EM the percentage of spines labeled for either $D_{1}$ or $D_{2}$ (or both) and determined the size and shape of those terminals making asymmetric axospinous synaptic contacts on immunolabeled spine heads. Terminals were again measured at their widest diameter parallel to the postsynaptic density. Note that although indirect pathway striato-GP neurons in rat characteristically contain enkephalin (ENK) and direct pathway striatonigral neurons characteristically contain SP, immunolabeling for these neuropeptides does not provide a reliable means for labeling the perikarya and dendrites of these neuron types, because they appear to rapidly ship the neuropeptides to their terminals in GP and substantia nigra, respectively, and retain little in their perikarya and dendrites (Anderson and Reiner, 1990).

Finally, to directly determine whether IT-type terminals preferentially contact either striato-GP or striatonigral neurons, nine rats received unilateral injections of BDA10k (dextran, biotinylated, 10,000 MW, anionic, lysine fixable; Molecular Probes) into motor cortex on the left side of the brain. In these cases, anterograde corticostriatal labeling in the right striatum would be limited to IT-type terminals, because PT-type corticostriatal neurons do not project to contralateral striatum, but IT-type neurons do (Cowan and Wilson, 1994; Reiner et al., 2003). Before the surgery required for the injection of the $\mathrm{BDA} 10 \mathrm{k}$, the animals were deeply anesthetized with $0.1 \mathrm{ml} / 100 \mathrm{mg}$ of a mixture of ketamine (87 $\mathrm{mg} / \mathrm{kg}$ ) and xylazine $(13 \mathrm{mg} / \mathrm{kg})$. A $1 \mu \mathrm{l}$ Hamilton microsyringe was used to inject $5 \%$ BDA10k in $0.1 \mathrm{~m}$ phosphate buffer (PB), $\mathrm{pH} 7.4$, using stereotaxic methods as described previously (Reiner et al., 2000, 2003), using coordinates from the Paxinos and Watson (1998) stereotaxic atlas of the rat brain to target the injections. To directly determine whether PT-type terminals preferentially contact either indirect pathway striato-GP or direct pathway striatonigral neurons, in seven other rats, $0.15 \mu \mathrm{l}$ of $10 \%$ BDA3k (dextran, biotinylated, $3000 \mathrm{MW}$, anionic, lysine fixable; Molecular Probes) in $0.1 \mathrm{~m}$ sodium citrate-HCl, pH 3.0 (Reiner et al., 2000), was injected bilaterally, using a $1 \mu$ l Hamilton microsyringe, into the pyramidal tract at caudal pontine levels to produce selective labeling of the intrastriatal collaterals of these neurons (Reiner et al., 2003), using stereotaxic coordinates from the atlas of Paxinos and Watson (1998). Alternate sections from rats with successful labeling of IT-type or PT-type terminals in right striatum were then processed for $\mathrm{D}_{1}$ or $\mathrm{D}_{2}$ immunolabeling, and all were processed for $\mathrm{ABC}$ visualization of the terminal labeling. As in our second line of study, $D_{1}$ immunolabeling served as a way of preferentially detecting direct pathway striatonigral neurons and $\mathrm{D}_{2}$ immunolabeling as a means for preferentially detecting indirect pathway striato-GP neurons. To analyze this material, we used EM to locate BDA-labeled terminals that made asymmetric synaptic contact with spine heads in the striatum. For each such terminal, we tabulated whether the spine head contacted was immunolabeled (for $\mathrm{D}_{1}$ in $\mathrm{D}_{1}$-immunolabeled tissue or for $\mathrm{D}_{2}$ in $\mathrm{D}_{2}$-immunolabeled tissue). This 
information was used to determine the percentage of IT-type and PTtype terminals synaptically contacting either $\mathrm{D}_{1}$ or $\mathrm{D}_{2}$ spines. We also counted all labeled and unlabeled spines not receiving a BDA+ asymmetric synaptic input in these same fields of view. This information was used to determine the percentage of $\mathrm{D}_{1}$ and $\mathrm{D}_{2}$ spines in the fields examined that received an asymmetric synaptic contact from an IT-type or PT-type terminal. The size of the BDA + terminals was also measured, again at the widest diameter parallel to the postsynaptic density. Synaptic contacts in all studies were identified by the presence of synaptic vesicles in the terminal and a postsynaptic density in the target spine.

Tissue fixation and processing. After 7-10 d, the rats that had been injected with BDA for ultrastructural visualization of retrogradely BDA3k-labeled striatal projection neuron spines or BDA-labeled intrastriatal corticostriatal terminals were deeply anesthetized with $0.8 \mathrm{ml}$ of $35 \%$ chloral hydrate in saline and then perfused transcardially as by Reiner et al. (2003). The rats were first exsanguinated by perfusion with $30-50 \mathrm{ml}$ of $6 \%$ dextran in $\mathrm{PB}$, followed by $400 \mathrm{ml}$ of $3.5 \%$ paraformaldehyde $-0.6 \%$ glutaraldehyde- $15 \%$ saturated picric acid in $\mathrm{PB}, \mathrm{pH}$ 7.4. The brain of each was then removed, postfixed overnight in the same fixative without glutaraldehyde, and then sectioned at $50 \mu \mathrm{m}$ on a vibratome. Rats without BDA injections that were to be used for studies of the size of axospinous terminals on $\mathrm{D}_{1}$ - or $\mathrm{D}_{2}$-immunolabeled spines $(n=4)$ were similarly transcardially perfused with fixative. Tissue with retrograde $\mathrm{BDA} 3 \mathrm{k}$ labeling of striato-GP or striatonigral neurons was next processed for visualization of the BDA. Tissue intended solely for study of the size and shape of axospinous terminals on $\mathrm{D}_{1}$ immunolabeled or $\mathrm{D}_{2}$-immunolabeled spines, on the other hand, was processed immunocytochemically with anti- $\mathrm{D}_{1}$ or anti- $\mathrm{D}_{2}$. Finally, tissue intended for simultaneous visualization of BDA labeling of corticostriatal terminals and immunolabeling of $\mathrm{D}_{1}$ and $\mathrm{D}_{2}$ dopamine receptors was processed first by the $\mathrm{ABC}$ procedure for $\mathrm{BDA}$ localization and then immunolabeled for $\mathrm{D}_{1}$ or $\mathrm{D}_{2}$. These various approaches are described in more detail in the following sections.

Visualization of dextran amines. Single-label visualization of BDA with light microscopy (LM) was used to ascertain the accuracy of injection sites, the abundance of retrogradely labeled striatonigral and striato-GP neurons in cases in which BDA had been injected into striatal target areas, or the abundance of BDA-labeled IT-type or PT-type terminals in cases in which the BDA had been injected into cortex or pons. Additional sections through the striatum from each case were processed for EM viewing. All sections were first pretreated with $1 \%$ sodium borohydride in $0.1 \mathrm{M}$ PB for $30 \mathrm{~min}$ followed by incubation in $0.3 \% \mathrm{H}_{2} \mathrm{O}_{2}$ solution in $0.1 \mathrm{M} P B$ for $30 \mathrm{~min}$. BDA was then visualized by using the ABC Elite kit (Vector Laboratories, Burlingame, $\mathrm{CA}$ ) from which a $5 \mathrm{ml}$ volume of the $\mathrm{ABC}$ solution was prepared in $0.01 \mathrm{~m}$ PBS by adding $50 \mu \mathrm{l}$ of avidin-DH and $50 \mu \mathrm{l}$ of biotinylated horseradish peroxidase. Sections were incubated in this solution for $1-2 \mathrm{hr}$ at room temperature or overnight at $4^{\circ} \mathrm{C}$ (Reiner et al., 2000). After PB rinses, the sections were immersed for $10-15 \mathrm{~min}$ in $0.05 \%$ diaminobenzidine tetrahydrochloride (DAB) (Sigma, St. Louis, MO) in 0.1 м PB, pH 7.2, containing $0.04 \%$ nickelammonium sulfate. Hydrogen peroxide was then added to the solution to a final concentration of $0.01 \%$, and the sections were incubated in this solution for an additional $15 \mathrm{~min}$. The sections were subsequently washed six times in PB. Sections to be viewed by LM were mounted onto gelatin-coated slides, dried, and then dehydrated, cleared with Pro-par (Anatech, Battle Creek, MI) or xylene, and coverslipped with Permount (Fisher Scientific, Pittsburgh, PA). Tissue to be examined by EM was rinsed, dehydrated, and flat embedded in plastic, as described below.

Single immunolabeling for $D_{1}$ and $D_{2}$ dopamine receptors. Sections were first pretreated with $1 \%$ sodium borohydride in $0.1 \mathrm{M} \mathrm{PB}$ for $30 \mathrm{~min}$ followed by incubation in $0.3 \% \mathrm{H}_{2} \mathrm{O}_{2}$ solution in $0.1 \mathrm{M} \mathrm{PB}$ for $30 \mathrm{~min}$. Alternate sections from each rat were incubated in rat anti- $\mathrm{D}_{1}$ (product

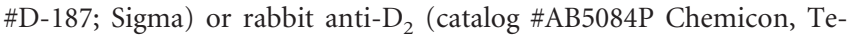
mecula, CA). These antibodies are selective for the 97 amino acid C-terminal fragment of human $\mathrm{D}_{1}$ and a 28 amino acid fragment within the third cytoplasmic loop (aa 284-311) of human $\mathrm{D}_{2}$ (common to short and long isoforms), respectively (Hersch et al., 1995; Wang and Pickel, 2002). To carry out conventional single-label immunohistochemistry, sections were incubated for $72 \mathrm{hr}$ at $4^{\circ} \mathrm{C}$ in primary antiserum diluted
1:500 $\left(D_{1}\right)$ or 1:200 $\left(D_{2}\right)$ (or for some additional sections with both simultaneously) with $0.1 \mathrm{~m}$ Tris buffer containing $4 \%$ normal goat serum- $-1.5 \%$ bovine serum albumin. Sections were then rinsed and incubated in donkey anti-rat IgG or anti-rabbit IgG diluted 1:80 in $0.1 \mathrm{M}$ Tris buffer, pH 7.4 (or both in cases in which the tissue had been incubated in both anti- $\mathrm{D}_{1}$ and anti- $\mathrm{D}_{2}$ ), followed by incubation in the appropriate rat or rabbit PAP complex diluted 1:200 in 0.1 M Tris buffer, $\mathrm{pH} 7.4$ (or both in cases in which the tissue had been incubated in both anti- $\mathrm{D}_{1}$ and anti- $\mathrm{D}_{2}$ ), with each incubation at room temperature for $1 \mathrm{hr}$. The sections were rinsed between secondary and PAP incubations in three $5 \mathrm{~min}$ washes of PB. Subsequent to the PAP incubation, the sections were rinsed with three to six $10 \mathrm{~min}$ washes in $0.1 \mathrm{M} \mathrm{PB}$, and a peroxidase reaction using $\mathrm{DAB}$ was performed. After the $\mathrm{PB}$ rinses, the sections were immersed for $10-15 \mathrm{~min}$ in $0.05 \% \mathrm{DAB}$ (Sigma) in $0.1 \mathrm{M} \mathrm{PB}, \mathrm{pH} 7.2$. Hydrogen peroxide was then added to a final concentration of $0.01 \%$, and the sections were incubated in this solution for an additional $15 \mathrm{~min}$. The sections were subsequently washed six times in PB. Sections to be viewed by LM were mounted onto gelatin-coated slides, dried, and then dehydrated, cleared with Pro-par (Anatech) or xylene, and coverslipped with Permount (Fisher Scientific). Tissue to be examined by EM was rinsed, dehydrated, and flat embedded in plastic, as described below.

Combined BDA labeling of terminals and immunolabeling for $\mathrm{D}_{1}$ and $\mathrm{D}_{2}$ dopamine receptors. A two-color DAB procedure (Reiner et al., 2000, 2003) was used to double label tissue for visualization of BDA-labeled corticostriatal terminals and immunolabeled dopamine receptors, for both LM and EM viewing. The sections were first pretreated with $1 \%$ sodium borohydride in $0.1 \mathrm{M} \mathrm{PB}$ for $30 \mathrm{~min}$ followed by incubation in $0.3 \% \mathrm{H}_{2} \mathrm{O}_{2}$ solution in $0.1 \mathrm{M} \mathrm{PB}$ for $30 \mathrm{~min}$. BDA was then visualized by using the $\mathrm{ABC}$ Elite kit (Vector Laboratories), using a nickel-intensified $\mathrm{DAB}$ procedure as described above. These sections were subsequently washed six times in $\mathrm{PB}$, and immunohistochemical labeling for $\mathrm{D}_{1}$ or $\mathrm{D}_{2}$ was performed using a brown $\mathrm{DAB}$ reaction to visualize the $\mathrm{D}_{1}$ or $\mathrm{D}_{2}$ immunolabeling, as described above. For each BDA-injected case used for simultaneously visualizing corticostriatal terminals and striatal dopamine receptors, some sections were prepared for LM viewing. These sections were mounted onto gelatin-coated glass slides, dried, dehydrated, cleared with Pro-par (Anatech) or xylene, and coverslipped with Permount (Fisher Scientific). Tissue to be examined at the EM level was rinsed, dehydrated, and flat embedded in plastic, as described in more detail in the following section. In the tissue prepared by such two-color DAB labeling, at the LM level, the BDA-filled corticostriatal terminals are distinctly labeled black with nickel-intensified $D A B$, and the dopamine receptor-bearing structures are immunolabeled with a brown $\mathrm{DAB}$ reaction. The LM tissue provided a means for evaluating the efficacy of the two labeling procedures in the double-labeled tissue. At the EM level, the black nickel-intensified $\mathrm{DAB}$ reaction product resembles the brown $\mathrm{DAB}$ reaction in its diffuse and flocculent appearance. Nonetheless, DAB was used to visualize both the BDA labeling and the $\mathrm{D}_{1}$ or $\mathrm{D}_{2}$ immunolabeling because of the superior sensitivity of DAB compared with other chromogens detectable at the EM level (Wouterlood et al., 1993). The similarity in appearance of the nickel-intensified and standard brown DAB reaction products at the EM level was not a hindrance to our interpretations for several reasons. First, because corticostriatal terminals and dendritic spines of striatal neurons are morphologically distinct structures, the BDA labeling of terminals could be readily distinguished from immunolabeling of spines for $D_{1}$ and $D_{2}$ (see Fig. 2). Second, because BDAlabeled corticostriatal terminals were intensely labeled with $\mathrm{DAB}$, they could be distinguished from any rare $\mathrm{D}_{1}$ or $\mathrm{D}_{2}$ immunolabeling of excitatory axospinous synaptic terminals, because the $\mathrm{D}_{1^{-}}$or $\mathrm{D}_{2^{-}}$ immunolabeled terminals tended to be only lightly labeled, as previously noted (Hersch et al., 1995). Moreover, $\mathrm{D}_{1}$ - and $\mathrm{D}_{2}$-immunolabeled terminals were rare in our material, with only $3.1 \%$ of all asymmetric axospinous synaptic terminals labeled for $\mathrm{D}_{1}$ and $5.7 \%$ of all asymmetric axospinous synaptic terminals labeled for $\mathrm{D}_{2}$, with neither type showing an evident tendency to preferentially synapse with or avoid immunolabeled spines. Thus, any possible densely immunolabeled terminals that might have been mistaken for BDA-labeled terminals would have been infrequent and would not have biased the counts of corticostriatal synaptic targeting in favor of any particular spine type. Finally, because BDA 
injections into pons or cortex do not yield labeling of striatal neurons, because spiny neurons do not project to either site (Reiner et al., 1990), use of the same chromogen did not yield BDAlabeled spines that might be confused with dopamine receptor-immunolabeled spines.

Preparation of tissue for EM. After BDA visualization as described above (in the case of BDA-labeled tissue) or immunolabeling for $\mathrm{D}_{1}$ or $\mathrm{D}_{2}$ as described above (in the case of tissue used for determination of terminal size on $\mathrm{D}_{1}$ and $\mathrm{D}_{2}$-labeled spines or tissue with concurrent dopamine receptor immunolabeling of spines and BDA labeling of corticostriatal terminals), the sections were rinsed in $0.1 \mathrm{M}$ sodium cacodylate buffer, $\mathrm{pH} 7.2$, postfixed for $1 \mathrm{hr}$ in $2 \%$ osmium tetroxide $\left(\mathrm{OsO}_{4}\right)$ in $0.1 \mathrm{~m}$ sodium cacodylate buffer, dehydrated in a graded series of ethyl alcohols, impregnated with $1 \%$ uranyl acetate in $100 \%$ alcohol, and flat embedded in Spurr's resin (Electron Microscopy Sciences, Fort Washington, PA). For the flat embedding, the sections were mounted on microslides pretreated with liquid releasing factor (Electron Microscopy Sciences). The Spurr's resinembedded sections were examined light microscopically for the presence of BDA-labeled axons and terminals in striatum. Pieces of embedded tissue were then cut from the striatum and glued to carrier blocks, and ultrathin sections were cut from these specimens with a Reichert ultramicrotome. The sections were mounted on mesh grids, stained with $0.4 \%$ lead citrate and $4.0 \%$ uranyl acetate using an LKBWallac (Gaithersburg, MD) Ultrastainer, and finally viewed and photographed with a Jeol (Peabody, MA) 1200 electron microscope. One or more series from each case used for ultrastructural analysis were also routinely processed for LM visualization of BDA labeling. Analysis and quantification was performed using the photographs of the EM labeling. LM and EM images were scanned and imported into Adobe Photoshop (Adobe Systems, San Jose, CA) to prepare the illustrations presented here.

\section{Results}

Size of terminals making asymmetric synaptic contact with spines of retrogradely labeled striatonigral versus striato-GP neurons

In three rats, numerous neurons were labeled in the ipsilateral striatum after accurate $\mathrm{BDA} 3 \mathrm{k}$ injection into the substantia nigra on one side of the brain (Figs. $1 A, C$,

$2 A, B)$. In one additional rat, numerous neurons were labeled on each side after accurate BDA3k injection into each nigra. Similarly, in one rat, many neurons were labeled in the ipsilateral striatum after accurate BDA3k injection in the GP, on one side of the brain, and in two additional rats, numerous neurons were labeled on each side after accurate BDA3k injection into each GP (Figs. $1 B, D, 3 C, D$ ). Camera lucida drawings of retrogradely labeled striatonigral and striato-GP neurons indicated that the perikaryal size of the two neuron types and the dendritic labeling of the two neuron types was indistinguishable, typically including evident labeling of tertiary and quaternary branches (Fig. $3 B, D$ ). Electron microscopic analysis revealed labeling of dendritic tatory inputfrom cortex.

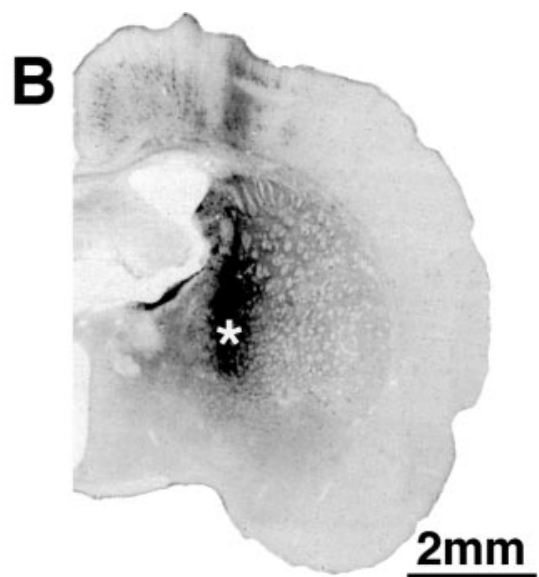

$1 \mathrm{~mm}$
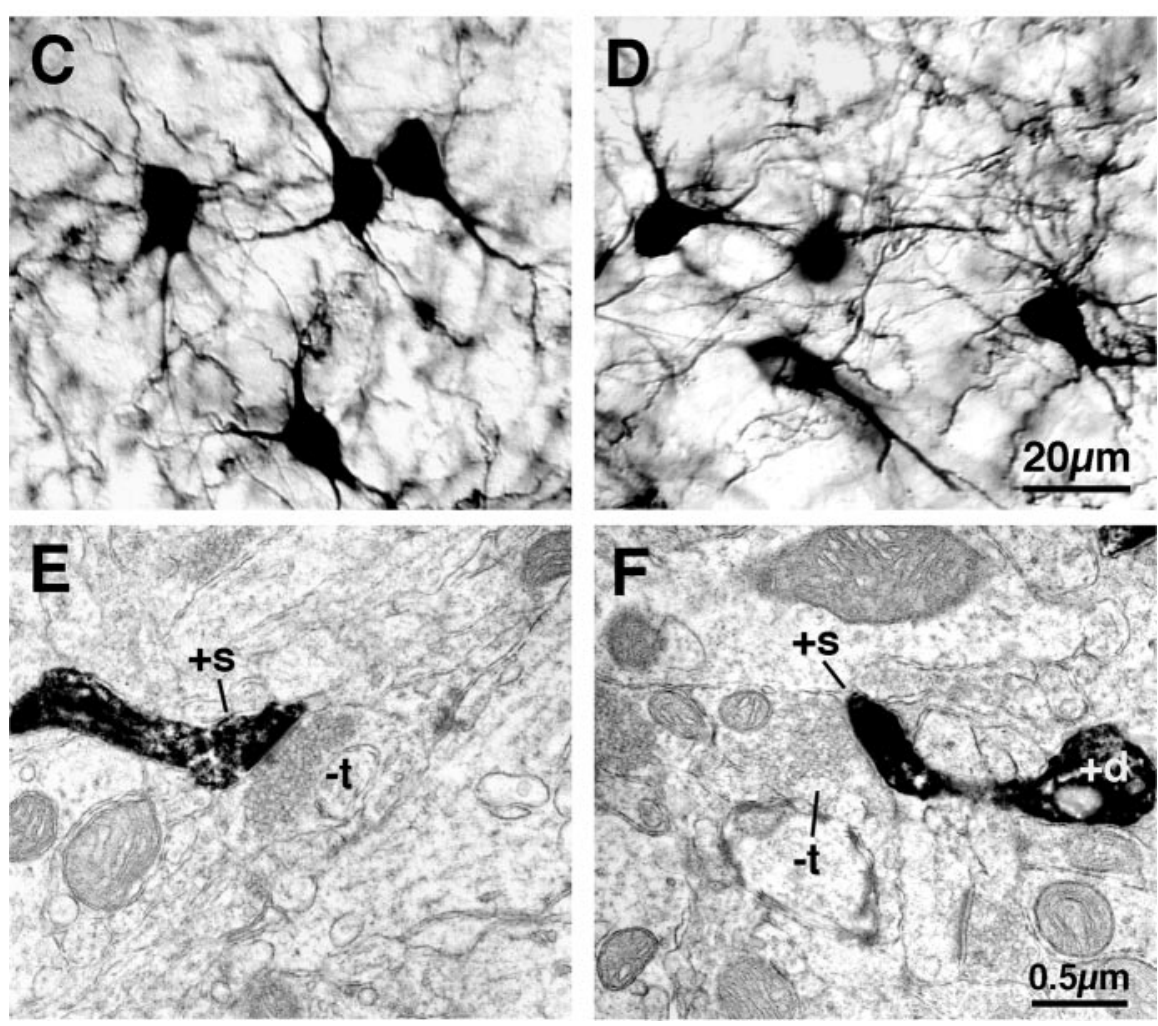

Figure 1. Examples of BDA3k injection sites (asterisks) in the substantia nigra $(A)$ and GP at low magnification, higher-power images showing examples of retrogradely labeled striatal neurons from such injections $(C, D)$, and sample ultrastructural views of retrogradely labeled dendrites and spines of striatonigral $(E)$ and striato-GP $(F)$ neurons. Images $C$ and $D$ show that the perikarya labeling included that of spines. BDA3k-labeled dendrites $(+d)$ and spines $(+s)$ are evident in $E$ and $F$, and the labeled spines in each receive asymmetric synaptic contact from an unlabeled terminal $(-\mathrm{t})$ containing the round vesicles characteristic of exci-

spines of both neuron types as well (Fig. 4). Statistical analysis (by $t$ tests) indicated no significant difference in the number and length of primary or higher-order dendritic branches between the two types of neurons or in perikaryal size. Analysis at the EM level revealed that asymmetric axospinous synaptic terminals on BDA-labeled striatonigral neuron spines were characteristically small (average of $0.43 \pm 0.003 \mu \mathrm{m}$ in diameter for 309 such terminals) and regular in shape (see Table 2, Fig. $4 A, B$ ). In contrast, asymmetric axospinous synaptic terminals on BDA3klabeled striato-GP neuron spines were characteristically larger (average of $0.69 \pm 0.017 \mu \mathrm{m}$ in diameter for 342 such terminals) and more commonly irregular in shape (Table 1, Fig. 4C,D). 


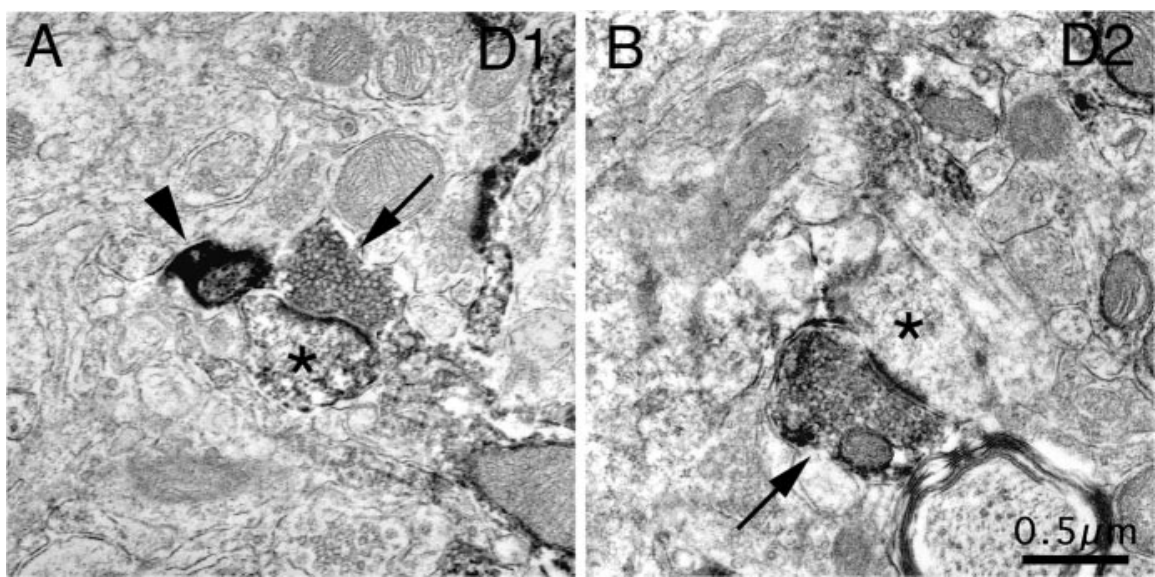

Figure 2. Electron microscopic images of immunolabeling of rat striatum for $D_{1}$ from tissue in which IT-type terminals were labeled with BDA10k $(A)$ and for $D_{2}$ from tissue in which PT-type terminals were labeled with $\operatorname{BDA3k}(B)$, showing representative examples (arrows) of $D_{1}$-immunolabeled $(A)$ and $D_{2}$-immunolabeled $(B)$ asymmetric axospinous synaptic terminals, with the recipient spines indicated by asterisks. The immunolabeled terminals were far less intensely labeled than BDA-labeled terminals, an example of which is indicated in $A$ (arrowhead).
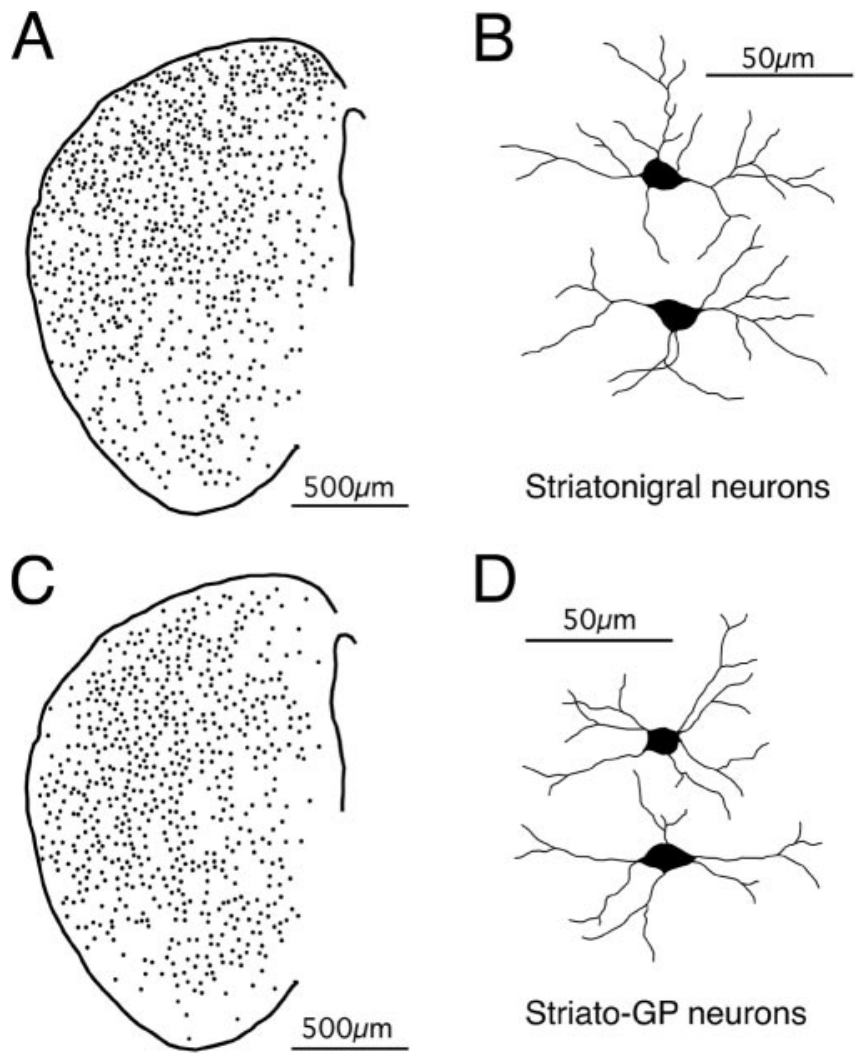

Striato-GP neurons

Figure 3. Camera lucida drawings showing the comparable distributions of BDA3k retrogradely labeled striatonigral $(A)$ and striato-GP $(C)$ neurons and the similar extent of labeling for each neuron type $(B, D)$ in representative cases for each.

Additionally, the synaptic zone in many cases (as judged by the postsynaptic density) tended to be lengthy and discontinuous. Thus, retrogradely labeled striatonigral and striato-GP neurons commonly differed in the size and shape of the terminals making asymmetric synaptic contact with their spines, with the terminal size difference being highly significant (Table 1, Fig. 5). Given that the dendrites of the two neuron types were labeled to a similar extent, it seems unlikely that the difference in terminal size and shape stemmed from a bias toward sampling different parts of the dendritic tree of the two neuron types.

\section{Size of terminals making asymmetric} synaptic contact with $D_{1}$ - versus $\mathrm{D}_{2}$-immunolabeled spines

Immunostaining for $\mathrm{D}_{1}, \mathrm{D}_{2}$, and $\mathrm{D}_{1}$ plus $\mathrm{D}_{2}$ was intense in striatum, with little labeling in cortex (Fig. 6A-C). Highmagnification LM viewing revealed the immunostaining to be localized to striatal neuronal perikarya and dendrites, primarily along the cell membrane inner surfaces (Fig. 6D-F). EM additionally revealed labeling of spines (Figs. 6G-I). Counts of labeled spines at the EM level in random fields showed that the mean percentage $\left( \pm\right.$ SEM) of spines labeled for $D_{1}$ was $47.2 \pm 2.4 \%$, for $\mathrm{D}_{2}$ was $46.2 \pm 1.6 \%$, and for $\mathrm{D}_{1}$ plus $\mathrm{D}_{2}$ was $89.4 \pm 0.7 \%$ (based on 1605 spines). Similar results have been reported previously by Hersch et al. (1995) for the relative frequencies of striatal spine immunolabeling for $D_{1}, D_{2}$, and $D_{1}$ plus $D_{2}$. The finding that the sum of the $\mathrm{D}_{1}$-immunolabeled and $\mathrm{D}_{2}$ immunolabeled spine frequencies only slightly exceeds that in the tissue simultaneously labeled for $\mathrm{D}_{1}$ plus $\mathrm{D}_{2}$ suggests $\mathrm{D}_{1}$ and $\mathrm{D}_{2}$ to be primarily localized to the spines of separate neuron types in our tissue. Studies by others suggest these separate neuron types to be striatonigral $\left(\mathrm{D}_{1}\right)$ versus striato-GP $\left(\mathrm{D}_{2}\right)$ projection neurons (Gerfen et al., 1990; Gerfen, 1992; Le Moine and Bloch, 1995). The mean size of terminals making asymmetric synaptic contact with $\mathrm{D}_{1}$-immunolabeled spines $(0.45 \pm 0.02 \mu \mathrm{m}$, based on 867 spines in four rats) was significantly smaller than the mean size of terminals making asymmetric synaptic contact with $\mathrm{D}_{2}$ immunolabeled spines $(0.61 \pm 0.05 \mu \mathrm{m}$, based on 519 spines in the same four rats) (Table 1, Figs. 5, 7).

Targetting of BDA-labeled IT-type and PT-type terminals to $D_{1}$ - versus $D_{2}$-immunolabeled spines

Counts of labeled spines at the EM level in the fields used for the analysis of BDA-labeled terminals on dopamine receptor immunolabeled spines showed that the mean percentage $( \pm S E M)$ of spines labeled for $\mathrm{D}_{1}$ in the $\mathrm{D}_{1}$-immunolabeled tissue was $50.7 \pm$ $1.7 \%$ (based on 1023 spines), and for $\mathrm{D}_{2}$ in the $\mathrm{D}_{2}$ immunolabeled tissue was $47.1 \pm 4.4 \%$ (based on 799 spines). Thus, the percentage of spines labeled for $\mathrm{D}_{1}$ or $\mathrm{D}_{2}$ in the doublelabeled material closely resembled that in the immunolabelingalone material, suggesting that combining BDA labeling and immunolabeling did not significantly alter the dopamine receptor immunolabeling of spines. Double labeling for IT-type corticostriatal terminals and the spines of direct pathway striatonigral neurons (via $\mathrm{D}_{1}$ immunolabeling) or of indirect pathway striato-GP neurons (via $\mathrm{D}_{2}$ immunolabeling) showed that of all axospinous asymmetric IT-type synaptic terminals labeled with BDA in tissue immunolabeled for $\mathrm{D}_{1}$, a mean $50.9 \%$ of the ITtype terminals (for six striata in six rats) contacted $D_{1}$ spines (Table 2, Fig. 8). In contrast, of all axospinous asymmetric ITtype synaptic terminals labeled with BDA in tissue immunolabeled for $\mathrm{D}_{2}$, only an average of $12.6 \%$ (for seven striata in six rats) contacted $\mathrm{D}_{2}$ spines. Thus, IT-type terminals labeled with BDA contacted $\mathrm{D}_{1}$ spines four times more commonly than they contacted $\mathrm{D}_{2}$ spines (significantly different at the 0.002 level by $t$ 

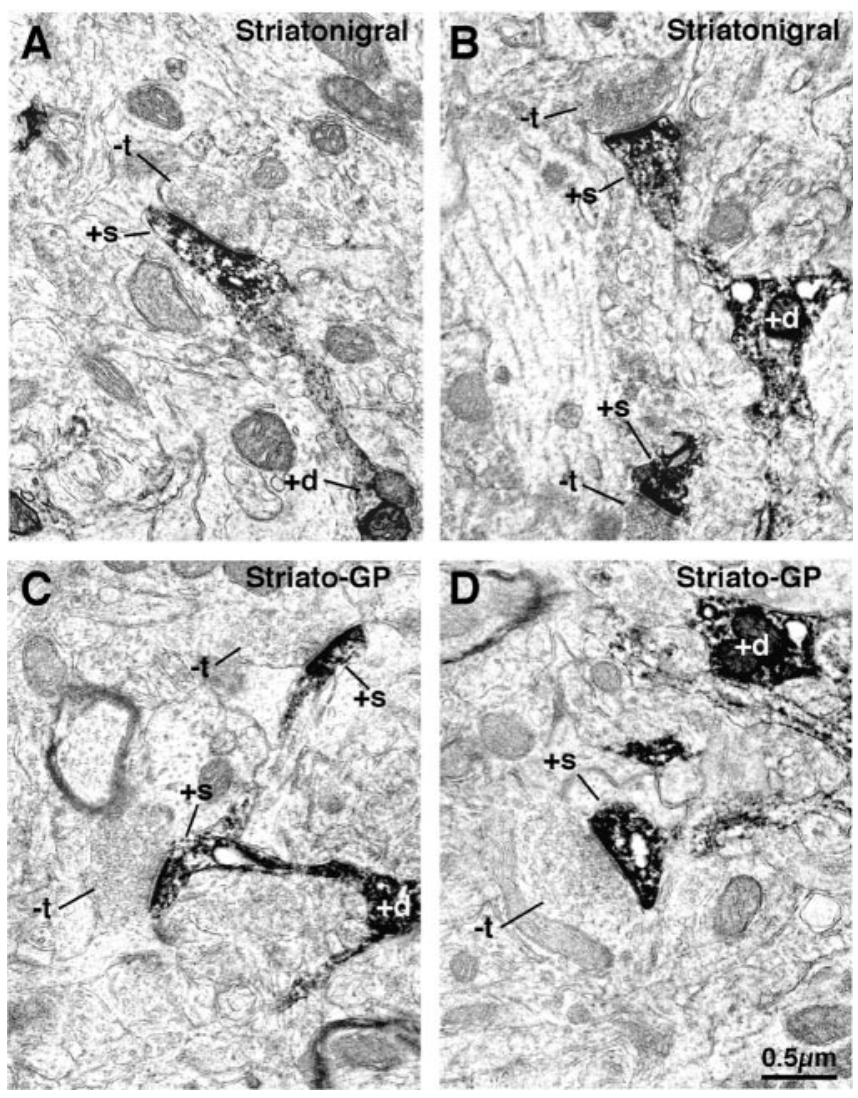

Figure 4. Electron microscopic images of dendrite $(+d)$ and spine $(+s)$ labeling of striatonigral $(A, B)$ and striato-GP $(C, D)$ neurons that had been retrogradely labeled with BDA3k. Note that the labeled striatonigral $(A, B)$ spines receive asymmetric synaptic contact from smaller unlabeled terminals $(-t)$ than do the striato-GP neuron spines $(C, D)$.

test). Double labeling for PT-type corticostriatal terminals and the spines of direct pathway striatonigral neurons (via $\mathrm{D}_{1}$ immunolabeling) or of indirect pathway striato-GP neurons (via $\mathrm{D}_{2}$ immunolabeling) showed a different trend; of all axospinous asymmetric PT-type synaptic terminals labeled with BDA in tissue immunolabeled for $\mathrm{D}_{1}$, only a mean of $21.3 \%$ of PT-type terminals (in five striata in five rats) contacted $\mathrm{D}_{1}$ spines, whereas of all axospinous asymmetric PT-type synaptic terminals labeled with $\mathrm{BDA}$ in tissue immunolabeled for $\mathrm{D}_{2}$, a mean of $50.5 \%$ (in five striata in four rats) contacted $\mathrm{D}_{2}$ spines (Table 2, Fig. 9). This difference for PT-type terminals was significantly at the 0.005 level by $t$ test. Thus, IT-type terminals preferentially contact $D_{1}$ spines, whereas PT-type terminals preferentially contact $\mathrm{D}_{2}$ spines. The data also show that IT-type terminals (Table 2) are significantly smaller $(0.40-0.43 \mu \mathrm{m})$ than PT-type terminals (Table 2) on both $\mathrm{D}_{1}$-immunolabeled and $\mathrm{D}_{2}$-immunolabeled spines $(0.68-0.72 \mu \mathrm{m})$, as would be expected from our previous findings on the mean size of IT-type and PT-type terminals on striatal spines (Reiner et al., 2003).

The preference of IT-type terminals for $\mathrm{D}_{1}$ spines and PT-type terminals for $\mathrm{D}_{2}$ spines is also evident when the data are used to calculate the percentage of spines of a given type that were observed to receive asymmetric IT-type or PT-type synaptic input (Table 3). For example, in the fields examined (i.e., all fields containing a labeled IT-type corticostriatal terminal making asymmetric synaptic contact with a spine head), a mean of $23.7 \%$ of $\mathrm{D}_{1}+$ spines (in six striata in six rats) received IT input, whereas significantly fewer $\mathrm{D}_{2}+$ spines (a mean of only $10.2 \%$ in five striata in five rats) received IT-type input. For PT-type terminals, a significant $\mathrm{D}_{2}+$ spine preference was evident. In the fields examined (i.e., all fields containing a labeled PT-type corticostriatal terminal making asymmetric synaptic contact with a spine head), a mean of $40.1 \%$ of $\mathrm{D}_{2}+$ spines received PT-type synaptic input (in five striata in four rats), whereas a mean of only $12.4 \%$ of $\mathrm{D}_{1}+$ spines (in seven striata in six rats) received PT input. The corticostriatal terminal difference for $\mathrm{D}_{2}$ spines was significant at the $p=0.0003$ level, whereas the difference for $D_{1}$ spines was nearly significant $(p=0.06)$. Thus, regardless of how the results of this study combining anterograde labeling of terminal types with immunolabeling of spines for $\mathrm{D}_{1}$ or $\mathrm{D}_{2}$ are examined, the findings consistently indicate that IT-type terminals preferentially contact the spines of direct pathway striatonigral neurons (preferentially possessing $\mathrm{D}_{1}$ ), and PT-type terminals preferentially target the spines of indirect pathway striato-GP neurons (preferentially possessing $\mathrm{D}_{2}$ ).

\section{Discussion}

Our three lines of study in rats suggest that IT input preferentially ends on direct pathway striatonigral neurons, whereas PT input preferentially ends on indirect pathway striato-GP neurons. This conclusion is consistent with previous evidence that although all striatal neurons respond to glutamatergic cortical input, the input to indirect pathway striatal neurons somehow differs from that to direct pathway neurons (Uhl et al., 1988; Zemanick et al., 1991; Berretta et al., 1997; Parthasarathy and Graybiel 1997).

\section{Main conclusions and technical considerations \\ Selective retrograde labeling of striatonigral and striato-GP neurons}

In our first line of study, we found the mean size of terminals making axospinous asymmetric synaptic contact with spines of striatal neurons retrogradely labeled with BDA3k from the sub-

Table 1. Comparison of axospinous synaptic terminal size on striatonigral and striato-GP neurons identified by retrograde labeling or dopamine receptor immunolabeling

\begin{tabular}{|c|c|c|c|}
\hline $\begin{array}{l}\text { Approach used to label striatal projection } \\
\text { neuron type }\end{array}$ & $\begin{array}{l}\text { Mean } \pm \text { SEM size of axospinous synaptic } \\
\text { terminals on striatonigral neurons }\end{array}$ & $\begin{array}{l}\text { Mean } \pm \text { SEM size of axospinous synaptic } \\
\text { terminals on striato-GP neurons }\end{array}$ & Significance by $t$ test \\
\hline $\begin{array}{l}\text { Retrograde BDA3k labeling from nigra } \\
\text { (striatonigral neurons) or GP (striato-GP } \\
\text { neurons) }\end{array}$ & $\begin{array}{l}0.43 \pm 0.003 \mu \mathrm{m}(n=309 \text { terminals } \\
\quad \text { in five striata })\end{array}$ & $\begin{array}{l}0.69 \pm 0.017 \mu \mathrm{m}(n=342 \text { terminals in five } \\
\text { striata })\end{array}$ & Significant at $p=0.0000005$ \\
\hline $\begin{array}{l}\text { Immunolabeled for } D_{1} \text { (striatonigral neurons) } \\
\text { or } D_{2} \text { (striato-GP neurons) }\end{array}$ & $0.45 \pm 0.02 \mu \mathrm{m}(n=867$ terminals in four striata $)$ & $0.61 \pm 0.05 \mu \mathrm{m}(n=519$ terminals in four striata $)$ & Significant at $p=0.02$ \\
\hline $\begin{array}{l}\text { Significance of retrograde labeling versus } \\
\text { immunolabeling difference in terminal } \\
\text { size by } t \text { test }\end{array}$ & $\begin{array}{l}\text { Terminal size for striatonigral neurons } \\
\text { retrogradely labeled versus } D_{1} \text { immunolabeled } \\
\text { not significantly different at } p=0.193\end{array}$ & $\begin{array}{l}\text { Terminal size for striato-GP neurons retrogradely } \\
\text { labeled versus } D_{2} \text { immunolabeled not } \\
\text { significantly different at } p=0.154\end{array}$ & \\
\hline
\end{tabular}



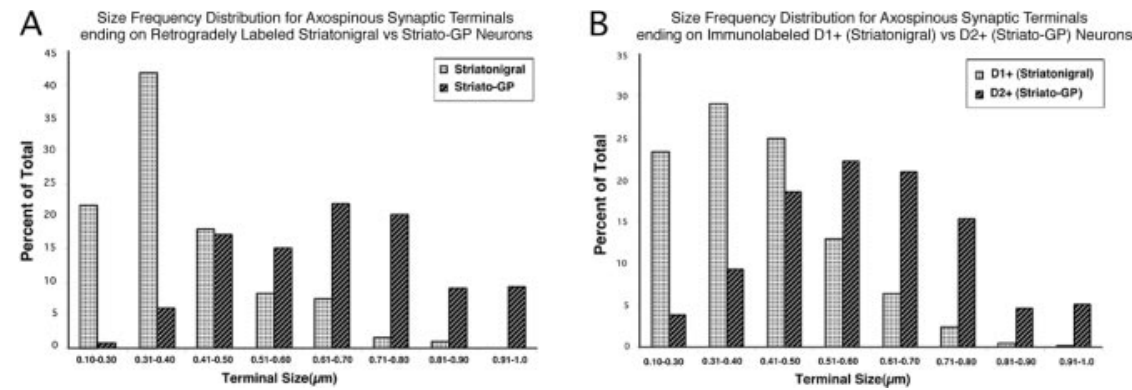

Figure 5. Histograms comparing the size frequency distribution of asymmetric synaptic terminals on striatonigral spines to the size frequency distribution of asymmetric synaptic terminals on striato-GP spines, with spine types based on either retrogradely labeling with $\operatorname{BDA3k}(A)$ or immunolabeling for $D_{1}$ or $D_{2}$ dopamine receptors $(B)$. In both $A$ and $B$, the frequency for each spine type is expressed as a percentage of the total number of asymmetric axospinous contacts counted for that spine type (309 BDA3k + striatonigral spines, 342 $\mathrm{BDA3k}+$ striato-GP spines, $867 \mathrm{D}_{1}+$ striatonigral spines, and 519 $\mathrm{D}_{2}+$ striato-GP spines). Note that the size range is lower and peak frequency less for terminals on labeled striatonigral neuron spines than on striato-GP neuron spines by either the retrograde labeling or immunolabeling method of identifying such spines. As shown in Table 2, the mean size of the asymmetric axospinous synaptic terminals on striatonigral neurons is also significantly less than on striato-GP neurons.
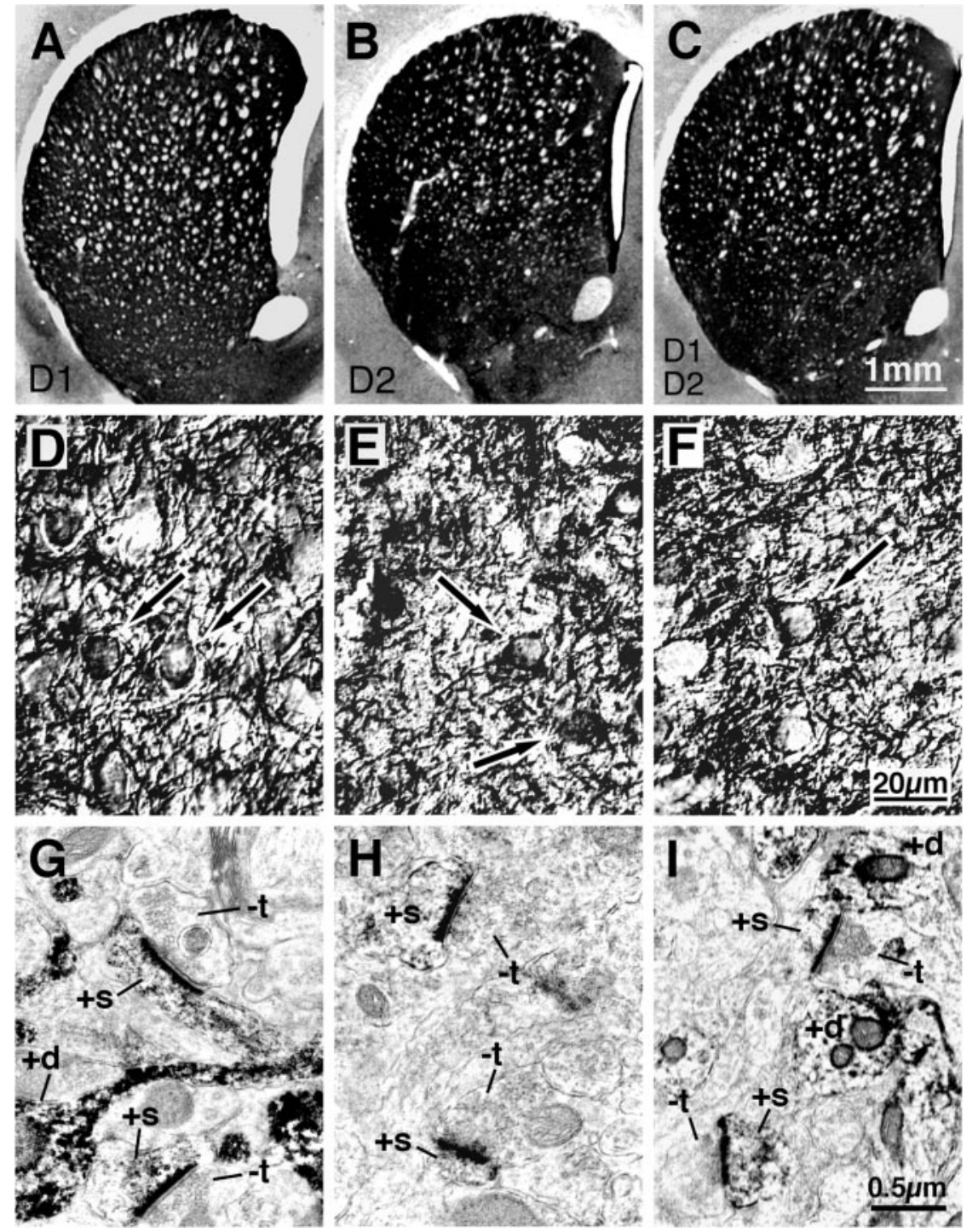

Figure 6. LM and EM images of immunolabeling of rat striatum for $D_{1}(A, D, G), D_{2}(B, E, H)$, or $D_{1}$ plus $D_{2}(C, F, I)$ dopamine receptors. The immunostaining for $D_{1}, D_{2}$, and $D_{1}$ plus $D_{2}$ was intense in striatum, with little in cortex, as revealed by the low-power $L M$ images $(A-$ C. High magnification LM viewing revealed the immunostaining to be localized to striatal neuron perikarya (arrows) and dendrites $(+d)$ $(D-F)$. EM viewing additionally revealed labeling of spines $(+s)$ receiving asymmetric synaptic contacts from terminals containing the round vesicles characteristic of the excitatory input from the cerebral cortex $(G-l)$. $-t$, Unlabeled terminals. stantia nigra $(0.43 \mu \mathrm{m})$ closely matched that previously reported by us for IT-type terminals $(0.41 \mu \mathrm{m})$ (Reiner et al., 2003). The uniformly small size of asymmetric axospinous terminals on neurons retrogradely labeled from nigra suggests that both striato-SNr (the predominant type projecting to nigra) and striato-EP neurons preferentially receive IT-type input. Because asymmetric axospinous thalamostriatal terminals are commonly closer in size to ITtype than PT-type terminals (Sadikot et al., 1992; Lei et al., 2004), our study suggests direct pathway neurons may receive thalamostriatal input as well. Sidibe and Smith (1996), in fact, reported that thalamostriatal terminals in monkey preferentially contact striato-GPi direct pathway rather than striato-GPe indirect pathway neurons.

Only one type of striatal neuron projects exclusively to GP, and these contain ENK (Parent et al., 1989, 1995; Kawaguchi et al., 1990; Reiner and Anderson, 1990; Wu et al., 2000). Although striatal neurons that project to nigra or EP, which commonly contain SP, have slight collateralization to GP (Kawaguchi et al., 1990; Wu et al., 2000), the sparseness of these collaterals makes it likely that true striato-GP neurons predominated among our striatal neurons retrogradely labeled from GP. This interpretation is consistent with our finding by single-cell reverse transcription (RT)-PCR that $70 \%$ of striatal neurons retrogradely labeled from GP in rat contain ENK but not SP (Wang et al., 2002). Interestingly, the mean size of axospinous synaptic terminals on striatal neurons labeled from GP $(0.69 \mu \mathrm{m})$ is as would be expected if $70 \%$ of labeled neurons were striato-GP neurons receiving $0.82 \mu \mathrm{m}$ PT-type terminals and $30 \%$ were striato-EP-SNr neurons receiving $0.41 \mu \mathrm{m}$ IT-type terminals $[(0.82 \mu \mathrm{m} \times 70 \%)+(0.41 \mu \mathrm{m} \times$ $30 \%)=0.69 \mu \mathrm{m}]$. Thus, our studies of retrogradely labeled striatal projection neurons suggest that PT-type terminals end preferentially on striato-GP neurons, and IT-type preferentially on striato-EP-SNr neurons.

Selective detection of striatonigral neurons by $D_{1}$ immunolabeling and striato-GP neurons by $\mathrm{D}_{2}$ immunolabeling

The localization of $\mathrm{D}_{1}$ and $\mathrm{D}_{2}$ receptors to striatal projection neurons has been controversial, with immunolabeling and in situ hybridization histochemistry (ISHH) favoring segregation of $\mathrm{D}_{1}$ to direct pathway neurons and $\mathrm{D}_{2}$ to indirect pathway neurons (Gerfen et al., 1990; Gerfen, 1992; Hersch et al., 1995; Le Moine and Bloch, 1995), and physiological, single-cell RT- 


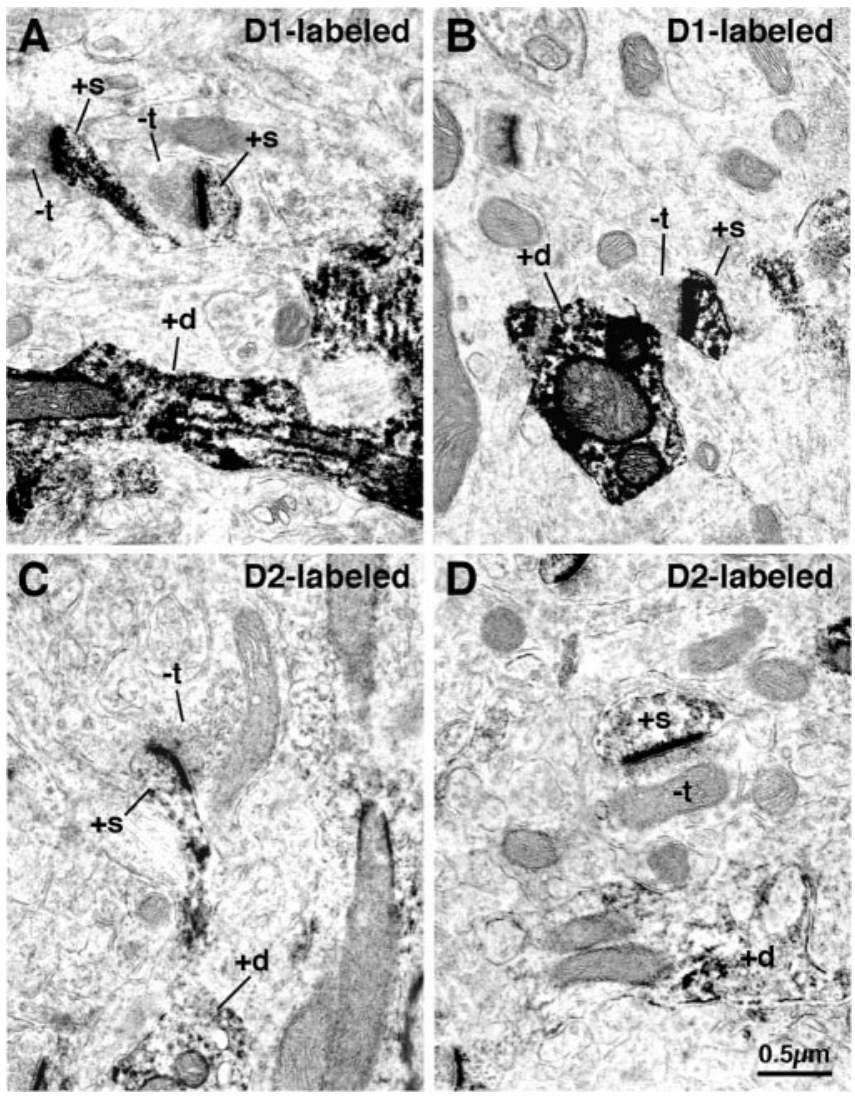

Figure 7. $D_{1}$-immunolabeled spines $(A, B)$ and $D_{2}$-immunolabeled spines $(C, D)$ in rat striatum at the EM level. Note that the $D_{1}$-immunolabeled spines $(+s)$, which presumptively primarily belong to striatonigral neurons, receive asymmetric synaptic contact from smaller unlabeled terminals $(-t)$ than do the $D_{2}$-immunolabeled spines, which presumptively primarily belong to striato-GP neurons. Labeled dendrites $(+d)$ are also evident in the fields of view shown.

PCR and some ISHH studies providing evidence for significant $\mathrm{D}_{1}-\mathrm{D}_{2}$ colocalization (Lester et al., 1993; Surmeier et al., 1993, 1996; Aizman et al., 2000). Although functionally significant $\mathrm{D}_{1}-\mathrm{D}_{2}$ colocalization may occur in some striatal projection neurons, our EM immunolabeling indicates that the $\mathrm{D}_{1}$ immunolabeled and $\mathrm{D}_{2}$-immunolabeled spines in our sample
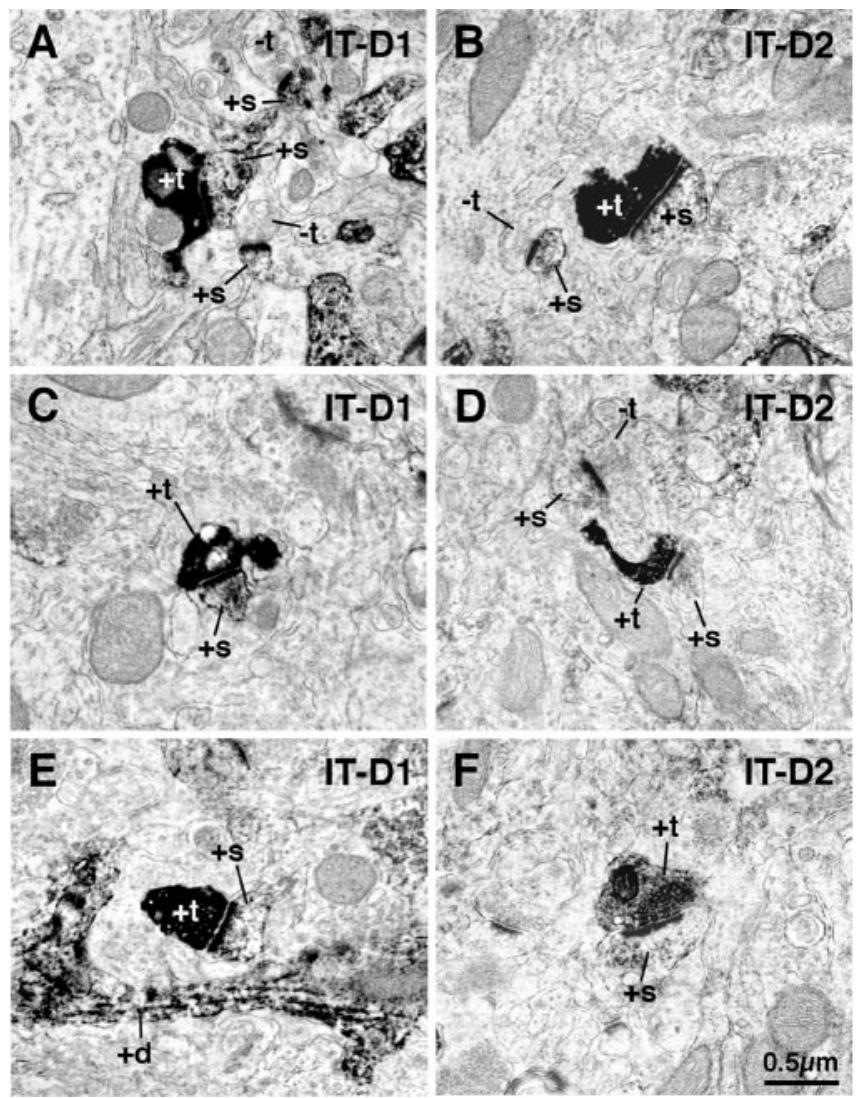

Figure 8. EM images showing double labeling for BDA10k-labeled IT-type corticostriatal terminals and $D_{1}$-immunolabeled $(+s)$ (striatonigral) spines in rat striatum $(A, C, E)$ and for BDA10k-labeled IT-type corticostriatal terminals and $D_{2}$-immunolabeled (striato-GP) spines ( $B$, $D, F)$. These images show that IT-type terminals make asymmetric synaptic contact with $D_{1}$ immunolabeled spines, as well as $D_{2}$-immunolabeled spines. As shown in Tables 2 and 3 , however, the IT-type terminals far more commonly contact $D_{1}$ than $D_{2}$ spines. $+d$, Labeled dendrites; $-\mathrm{t}$, unlabeled terminals; $+\mathrm{t}$, labeled terminals.

primarily belonged to different striatal projection neuron populations, with under $10 \%$ of $\mathrm{D}_{1}$ spines possessing $\mathrm{D}_{2}$ and under $10 \%$ of $\mathrm{D}_{2}$ spines possessing $\mathrm{D}_{1}$. In this light, our findings that the mean size of terminals making asymmetric synaptic contact with $\mathrm{D}_{1}$ spines $(0.45 \mu \mathrm{m})$ was similar to that of IT-type terminals $(0.41$

Table 2. Percentage of BDA-labeled IT-type versus PT-type terminals making axospinous synaptic contact with striatonigral versus striato-GP neurons, as identified by dopamine receptor immunolabeling

\begin{tabular}{|c|c|c|c|c|c|c|}
\hline $\begin{array}{l}\text { Type of spine targeted by } \\
\text { BDA + synaptic terminal }\end{array}$ & $\begin{array}{l}\text { Percentage of BDA + IT-type } \\
\text { terminal synapsing on given } \\
\text { spine type }\end{array}$ & $\begin{array}{l}\text { Percentage of BDA+ } \\
\text { PT-type terminal } \\
\text { synapsing on given } \\
\text { spine type }\end{array}$ & $\begin{array}{l}\text { Significance of IT-type } \\
\text { versus PT-type frequency } \\
\text { difference by } t \text { test }\end{array}$ & $\begin{array}{l}\text { Mean } \pm \text { SEM size of } \\
\text { BDA + IT-type } \\
\text { axospinous synaptic } \\
\text { terminal }\end{array}$ & $\begin{array}{l}\text { Mean } \pm \text { SEM size of } \\
\text { BDA+ PT-type } \\
\text { axospinous synaptic } \\
\text { terminal }\end{array}$ & $\begin{array}{l}\text { Significance of IT-type } \\
\text { versus PT-type size } \\
\text { difference by } t \text { test }\end{array}$ \\
\hline $\mathrm{D}_{1}+$ (striatonigral) & $\begin{array}{l}50.9 \% \text { (based on } 75 \text { BDA }+ \\
\text { IT-type synaptic terminals } \\
\text { on } \mathrm{D}_{1}+\text { spines in six striata) }\end{array}$ & $\begin{array}{l}\text { 21.3\% (based on } 39 \\
\text { BDA + PT-type } \\
\text { synaptic terminals on } \\
D_{1}+\text { spines in seven } \\
\text { striata) }\end{array}$ & $\begin{array}{l}\text { IT versus PT frequency on } \\
\mathrm{D}_{1}+\text { spines significantly } \\
\text { different at } p= \\
0.008\end{array}$ & $\begin{array}{c}0.40 \pm 0.016 \mu \mathrm{m} \\
(n=6 \text { striata })\end{array}$ & $\begin{array}{c}0.68 \pm 0.077 \mu \mathrm{m} \\
(n=5 \text { striata })\end{array}$ & $\begin{array}{l}\text { IT versus PT size } \\
\text { significantly different } \\
\text { on } \mathrm{D}_{1}+\text { spines at } p= \\
0.002\end{array}$ \\
\hline $\mathrm{D}_{2}+($ striato-GP) & $\begin{array}{l}\text { 12.6\% (based on } 29 \mathrm{BDA}+ \\
\text { IT-type synaptic terminals } \\
\text { on } \mathrm{D}_{2}+\text { spines in five striata) }\end{array}$ & $\begin{array}{l}\text { 50.5\% (based on } 68 \\
\text { BDA + PT-type } \\
\text { synaptic terminals on } \\
D_{2}+\text { spines in five } \\
\text { striata) }\end{array}$ & $\begin{array}{l}\text { IT versus PT frequency on } \\
\mathrm{D}_{2}+\text { spines significantly } \\
\text { different at } p=0.0003\end{array}$ & $\begin{array}{c}0.43 \pm 0.057 \mu \mathrm{m} \\
(n=3 \text { striata })\end{array}$ & $\begin{array}{c}0.72 \pm 0.041 \mu \mathrm{m} \\
(n=5 \text { striata })\end{array}$ & $\begin{array}{l}\text { IT versus PT size } \\
\text { significantly different } \\
\text { on } \mathrm{D}_{2}+\text { spines at } p= \\
0.003\end{array}$ \\
\hline $\begin{array}{l}\text { Significance of } D_{1} \text { versus } \\
D_{2} \text { difference by } t \text { test }\end{array}$ & $\begin{array}{l}D_{1} \text { versus } D_{2} \text { frequency of IT } \\
\text { synaptic input significantly } \\
\text { different at } p=0.002\end{array}$ & $\begin{array}{l}D_{1} \text { versus } D_{2} \text { frequency } \\
\text { of } P T \text { synaptic input } \\
\text { significantly different } \\
\text { at } p=0.005\end{array}$ & & $\begin{array}{l}\text { IT-type size not } \\
\text { significantly } \\
\text { different; } p=0.391\end{array}$ & $\begin{array}{l}\text { PT-type size not } \\
\quad \text { significantly } \\
\text { different; } p=0.578\end{array}$ & \\
\hline
\end{tabular}




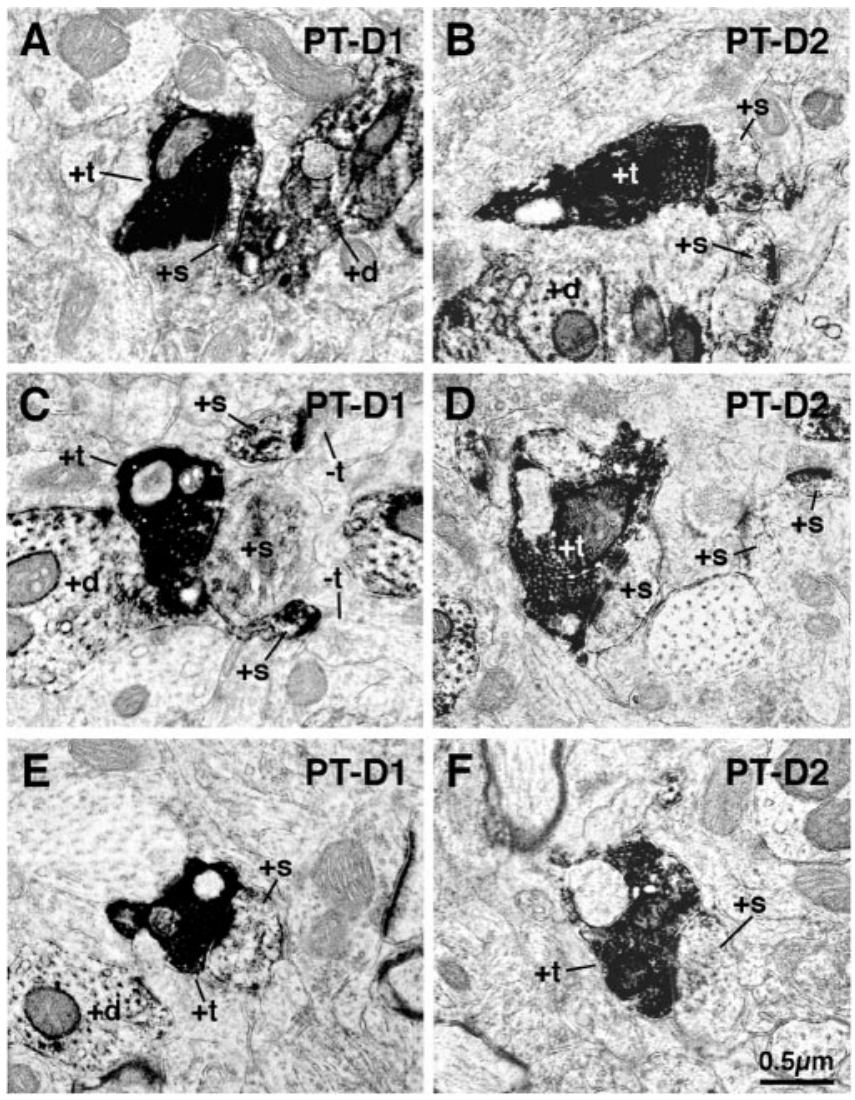

Figure 9. EM images showing double labeling for BDA3k-labeled PT-type corticostriatal terminals and $D_{1}$-immunolabeled (striatonigral) spines $(+s)$ in rat striatum $(A, C, E)$ and for BDA3k-labeled PT-type corticostriatal terminals and $D_{2}$-immunolabeled (striato-GP) spines ( $B$, $D, F)$. These images show that PT-type terminals make asymmetric synaptic contact with both $D_{1}$-immunolabeled spines, as well as $D_{2}$-immunolabeled spines. As shown in Tables 2 and 3 , however, the PT-type terminals far more commonly contact $D_{2}$ than $D_{1}$ spines. $+t$, Labeled terminals; $-t$, unlabeled terminals; $+d$, labeled dendrites.

$\mu \mathrm{m})$, whereas the mean size of terminals making asymmetric synaptic contact with $\mathrm{D}_{2}$ spines $(0.61 \mu \mathrm{m})$ was more similar to that of PT-type terminals $(0.82 \mu \mathrm{m})$ suggests, at the very least, that striato-EP-SNr neurons receive predominantly IT-type terminals, and striato-GP neurons receive many more PT-type terminals than do striato-EP-SNr neurons. The disparity between mean terminal size on $\mathrm{D}_{2}+$ spines and PT-type terminal size may not be as great as appears, because the mean size of PT-type terminals was less $(0.70 \mu \mathrm{m})$ in the current study combining spine immunolabeling with BDA terminal labeling than in our previous study of PT labeling alone $(0.82 \mu \mathrm{m})$ (Reiner et al., 2003). Using the measured mean size of PT-type terminals in the current $\mathrm{D}_{1}$ - and $\mathrm{D}_{2}$-immunolabeled tissue, it can be algebraically deduced from the size of the terminals on $\mathrm{D}_{1}$-immunolabeled spines that only $12.5 \%$ of the $\mathrm{D}_{1}$ spines immunolabeled in our second line of study received PT-type input. This slight PT input to $\mathrm{D}_{1}$ spines may reflect the existence of PT-recipient $\mathrm{D}_{1}+$ striato-GP neurons (possibly also possessing $\mathrm{D}_{2}$ ), which would be consistent with reports that $10-20 \%$ of striatal enkephalinergic neurons possess $\mathrm{D}_{1}$ (Surmeier et al., 1996; Waszczak et al., 1998). The minor PT input to $\mathrm{D}_{1}$ spines could also mean that some $\mathrm{D}_{1}+$ striatonigral neurons possess PT-recipient spines, which is consistent with our findings from our third line of study combining $\mathrm{D}_{1}$ spine immunolabeling with BDA-labeling of PT-type terminals.

Similarly, we algebraically deduced that only $32 \%$ of our $\mathrm{D}_{2}$ immunolabeled spines received terminals in the size range of IT-type or thalamic. This minor IT or thalamic input to $\mathrm{D}_{2}$ spines may stem from spines belonging to $\mathrm{D}_{2}+$ striatonigral-EP neurons (possibly also possessing $\mathrm{D}_{1}$ ), which would be consistent with reports that $\sim 20 \%$ of striatonigral neurons possess $\mathrm{D}_{2}$ (Gerfen et al., 1990; Surmeier et al., 1993). It is also possible that the minority axospinous input to $\mathrm{D}_{2}$ spines from small terminals reflects $\mathrm{D}_{2}+$ striato-GP neurons receiving IT input, which is consistent with our finding combining $\mathrm{D}_{2}$ immunolabeling with BDA-labeling of IT-type terminals that at least $10.2 \%$ of $\mathrm{D}_{2}$ spines receive IT-type input. The predominance of PT-type terminals relative to IT-type on $\mathrm{D}_{2}+$ spines revealed in our third line of study (Table 3), however, suggests that many of the small terminals on $\mathrm{D}_{2}+$ spines may arise from thalamus. In any event, our findings on the size of terminals on $\mathrm{D}_{2}$-immunolabeled spines in our second line of study indicate that PT-type terminals predominate on striato-GP neurons.

\section{Selective BDA labeling of IT-type and PT-type terminals}

Because not all IT-type neurons of motor cortex project to contralateral striatum (Wilson, 1987; Cowan and Wilson, 1994; Reiner et al., 2003), the synaptic targets of the contralateral ITtype terminals revealed in our third line of study may not be representative of all IT-type terminals. Two considerations argue against this possibility. First, although contralateral cortical projections differ from ipsilateral in their topographic organization and targeting of dendrites (Flaherty and Graybiel, 1993; Hersch et al., 1995), there is no evidence they differ in size, physiology, or the cell type targeted (Wilson, 1987; Cowan and Wilson, 1994; Wright et al., 1999, 2001). Second, the conclusion from our study of contralateral BDA10k-labeled IT-type terminals that IT-type terminals prefer striatonigral (i.e., $\mathrm{D}_{1}+$ ) spines is consistent with

Table 3. Percentage of striatonigral versus striato-GP neuron spines, as identified by dopamine receptor immunolabeling, receiving axospinous synaptic contact from BDA-labeled IT-type versus PT-type terminals

\begin{tabular}{|c|c|c|c|}
\hline $\begin{array}{l}\text { Type of spine targeted by BDA+ } \\
\text { synaptic terminal }\end{array}$ & $\begin{array}{l}\text { Percentage of spines with IT-type } \\
\text { axospinous synaptic terminal }\end{array}$ & $\begin{array}{l}\text { Percentage of spines with PT-type } \\
\text { axospinous synaptic terminal }\end{array}$ & $\begin{array}{l}\text { Significance of IT versus PT } \\
\text { frequency difference on spine } \\
\text { type by } t \text { test }\end{array}$ \\
\hline $\mathrm{D}_{1}+$ (striatonigral) & $\begin{array}{l}23.7 \% \text { (based on } 75 \text { BDA }+ \text { IT-type } \\
\text { synaptic terminals on } D_{1}+\text { spines in } \\
\text { six striata) }\end{array}$ & $\begin{array}{l}12.4 \% \text { (based on } 39 \mathrm{BDA}+\mathrm{PT} \text {-type } \\
\text { synaptic terminals on } \mathrm{D}_{1}+\text { spines in } \\
\text { seven striata) }\end{array}$ & $\begin{array}{l}\text { IT versus PT frequency on } \mathrm{D}_{1}+ \\
\text { spines not significantly } \\
\text { different; } p=0.06\end{array}$ \\
\hline $\mathrm{D}_{2}+($ striato-GP) & $\begin{array}{l}10.2 \% \text { (based on } 29 \mathrm{BDA}+\mathrm{IT} \text {-type } \\
\text { synaptic terminals on } \mathrm{D}_{2}+\text { spines in } \\
\text { five striata) }\end{array}$ & $\begin{array}{l}40.1 \% \text { (based on } 68 \mathrm{BDA}+\mathrm{PT} \text {-type } \\
\text { synaptic terminals on } \mathrm{D}_{2}+\text { spines in } \\
\text { five striata) }\end{array}$ & $\begin{array}{l}\text { IT versus PT frequency on } \mathrm{D}_{2}+ \\
\text { spines significantly different } \\
\text { at } p=0.0003\end{array}$ \\
\hline $\begin{array}{l}\text { Significance of } D_{1} \text { versus } D_{2} \\
\text { difference in corticostriatal } \\
\text { input type by } t \text { test }\end{array}$ & $\begin{array}{l}\text { Frequency of IT input significantly } \\
\text { different on } D_{1} \text { versus } D_{2} \text { spines at } p \\
=0.05\end{array}$ & $\begin{array}{l}\text { Frequency of PT input significantly } \\
\text { different on } D_{1} \text { versus } D_{2} \text { spines at } p \\
=0.0003\end{array}$ & \\
\hline
\end{tabular}


our studies of terminal size on retrogradely labeled or $\mathrm{D}_{1^{-}}$immunolabeled striatonigral spines. To selectively label PT-type terminals, we relied on the ability of BDA3k to label the intrastriatal collaterals of retrogradely labeled PT-type neurons (Reiner et al., 2000) and on the fact that IT-type neurons do not project extratelencephalically (Wilson, 1987; Cowan and Wilson, 1994). This approach, however, does not allow us to be sure of the cortical region giving rise to any particular BDA3k-labeled PT-type terminal. Although we overcame this limitation to some extent by examining only dorsolateral striatum, which receives its major input from somatomotor-somatosensory cortex (Alloway et al., 1998; Hoffer and Alloway, 2001), we do not know whether PTtype neurons of somatosensory and motor cortex equally prefer striato-GP neurons.

\section{Combining BDA labeling of terminals with immunolabeling of spines}

The double-labeling approach of our third line of study showed that IT-type terminals commonly contact $\mathrm{D}_{1}$ spines, whereas PTtype terminals commonly contact $\mathrm{D}_{2}$ spines. We also found that a higher percentage of $D_{1}$ spines received IT terminals than received PT, whereas a higher percentage of $\mathrm{D}_{2}$ spines received PT than IT. We presume that not all $\mathrm{D}_{1}$-immunolabeled or $\mathrm{D}_{2}$ immunolabeled spines received BDA-labeled terminals because not all corticostriatal terminals of a given type were BDA-labeled (notably IT-type terminals of ipsilateral origin were unlabeled), and some spines may have received thalamic input. One potential problem is that combining BDA labeling and immunolabeling could have decreased the frequency of $\mathrm{D}_{1^{-}}$and $\mathrm{D}_{2^{-}}$ immunolabeled spines from that in our study involving dopamine receptor immunolabeling alone, so as to lead to underrepresentation of one type of spine or the other. Our counts of $D_{1}$ - or $\mathrm{D}_{2}$-immunolabeled spines in the double-labeled tissue revealed, however, that this was not the case. Finally, Hersch et al. (1995) reported findings similar to ours for the percentage of contralateral BDA-labeled terminals (IT-type) arising from primary motor cortex (M1) that synapse on $\mathrm{D}_{1}$-immunolabeled spines, $47 \%$ in their study compared with $50.9 \%$ in ours. They, however, reported a much higher percentage of contralateral BDA-labeled terminals from $\mathrm{M} 1$ to synapse on $\mathrm{D}_{2}$-immunolabeled spines than we $\mathrm{did}, 52 \%$ versus $12.6 \%$. The basis of this disparity is uncertain, but may lie in the different anti- $\mathrm{D}_{2}$ used, which could have differed in their specificities in some manner not reflected in the frequency of spine labeling. Nonetheless, our conclusions about the target preference of IT-type and PT-type terminals from our double-label study are consistent with those of our first two lines of study.

\section{Functional implications}

Striato-EP-SNr neurons are thought to promote desired movement, and striato-GP neurons to inhibit unwanted movement (Albin et al., 1989; DeLong, 1990). Because PT-type input conveys a copy of the cortical motor signal (Miller, 1975; Oka and Jinnai, 1978; Landry et al., 1984; Mink, 1996), it may enable striato-GP neurons to inhibit behaviors that might otherwise conflict with movements initiated by the motor signal to brainstem. This may explain why striatal neurons that fire in association with movement commonly do not fire before movement onset (Jaeger et al., 1995; Mink, 1996). The larger size of PT-type terminals than IT-type and their tendency to be apposed to perforated postsynaptic densities may augment their synaptic efficacy (Geinisman, 1993; Sulzer and Pothos, 2000). This might explain why striato-GP neurons appear more responsive to cor- tical input than striato-EP-SNr neurons (Uhl et al., 1988; Parthasarathy and Graybiel 1997) and more avidly take up and anterogradely transmit the cortically injected H129 strain of herpes simplex virus (Zemanick et al., 1991). Perforated postsynaptic densities also indicate sites of synaptic potentiation (Geinisman, 1993; Geinisman et al., 1996; Sulzer and Pothos, 2000; Topni et al., 2001). Because the basal ganglia is involved in motor learning (Calabresi et al., 1992; Marsden and Obeso, 1994; Gabrieli, 1995; Graybiel and Kimura, 1995), the PT input to striato-GP neurons may participate in learned suppression of conflicting movements. Finally, the small size of the IT-type terminals and the diffuse nature of the IT projection to striatum may require synchrony of firing from diverse cortical areas for IT input to activate striato-EP-SNr neurons (Wilson, 1992). This is consistent with the presumed role of direct pathway neurons in promoting movement based on integration of diverse cortical input and with evidence for convergent projections from related cortical areas to individual striatal domains (Flaherty and Graybiel, 1991; Brown et al., 1998; Hoffer and Alloway, 2001).

\section{References}

Aizman O, Brismar H, Uhlen P, Zettergren E, Levey AI, Forssberg H, Greengard P, Asperia A (2000) Anatomical and physiological evidence for D1 and D2 dopamine receptor colocalization in neostriatal neurons. Nat Neurosci 3:226-230.

Albin RL, Young AB, Penney JB (1989) The functional anatomy of basal ganglia disorders. Trends Neurosci 12:366-375.

Alloway KD, Mutic JJ, Hoover JE (1998) Divergent corticostriatal projections from a single cortical column in the somatosensory cortex of rats. Brain Res 788:341-346.

Anderson KD, Reiner A (1990) Extensive co-occurrence of substance P and dynorphin in striatal projection neurons: an evolutionarily conserved feature of basal ganglia organization. J Comp Neurol 295:339-369.

Beloozerova IN, Sirota MG, Swadlow HA, Orlovsky GN, Popova LB, Deliagina TG (2003) Activity of different classes of neurons of the motor cortex during postural corrections. J Neurosci 23:7844-7853.

Berretta S, Parthasarathy HB, Graybiel AM (1997) Local release of GABAergic inhibition in the motor cortex induces immediate-early gene expression in indirect pathway neurons of the striatum. J Neurosci 17:4752-4763.

Brown LL, Smith DM, Goldbloom LM (1998) Organizing principles of cortical integration in the rat neostriatum: corticostriate map of the body surface is an ordered lattice of curved laminae and radial points. J Comp Neurol 392:468-488.

Calabresi P, Pisani A, Mercuri NB, Bernardi G (1992) Long-term potentiation in the striatum is unmasked by removing the voltage-dependent magnesium block of NMDA receptor channels. Eur J Neurosci 4:929-935.

Cowan RH, Wilson CJ (1994) Spontaneous firing patterns and axonal projections of single corticostriatal neurons in the rat medial agranular cortex. J Neurophysiol 71:17-32.

DeLong MR (1990) Primate models of movement disorders of basal ganglia origin. Trends Neurosci 13:281-285.

Desban M, Kemel ML, Glowinski J, Gauchy C (1993) Spatial organization of patch and matrix compartments in the rat striatum. Neuroscience 57:661-667.

Flaherty AW, Graybiel AM (1991) Corticostriatal transformations in the primate somatosensory system. Projections from physiologically mapped body-part representations. J Neurophysiol 66:1249-1263.

Flaherty AW, Graybiel AM (1993) Two input systems for body representations in the primate striatal matrix: experimental evidence in the squirrel monkey. J Neurosci 13:1120-1137.

Gabrieli J (1995) Contributions of the basal ganglia to skill learning and working memory in humans. In: Models of information processing in the basal ganglia (Houk JC, Davis JL, Beiser DG, eds), pp 277-294. Cambridge, MA: MIT.

Geinisman Y (1993) Perforated axospinous synapses with multiple, completely partitioned transmission zones: probable structural intermediates in synaptic plasticity. Hippocampus 3:417-433. 
Geinisman Y, de Toledo-Morrell L, Morrell F, Persina IS, Beatty MA (1996) Synapse restructuring associated with the maintenance phase of hippocampal long-term potentiation. J Comp Neurol 368:413-423.

Gerfen CR (1992) The neostriatal mosaic: multiple levels of compartmental organization in the basal ganglia. Annu Rev Neurosci 15:285-320.

Gerfen CR, Engber TM, Mahan LC, Susel Z, Chase TN, Monsma Jr FJ, Sibley DR (1990) D1 and D2 dopamine receptor-regulated gene expression of striatonigral and striatopallidal neurons. Science 250:1429-1432.

Graybiel AM, Kimura M (1995) Adaptive neural networks in the basal ganglia. In: Models of information processing in the basal ganglia (Houk JC, Davis JL, Beiser DG, eds), pp 103-116. Cambridge, MA: MIT.

Hersch SM, Ciliax BJ, Gutekunst CA, Rees HD, Heilman CJ, Yung KK, Bolam JP, Ince E, Yi H, Levey AI (1995) Electron microscopic analysis of $\mathrm{D}_{1}$ and $\mathrm{D}_{2}$ dopamine receptor proteins in the dorsal striatum and their synaptic relationships with motor corticostriatal afferents. J Neurosci 15:5222-5237.

Hoffer ZS, Alloway KD (2001) Organization of corticostriatal projections from the vibrissal representations in the primary motor and somatosensory cortical areas of rodents. J Comp Neurol 439:87-103.

Jaeger DJ, Gilman S, Aldridge JW (1995) Neuronal activity in the striatum and pallidum of primates related to the execution of externally cued reaching movements. Brain Res 694:111-127.

Kawaguchi Y, Wilson CJ, Emson PC (1990) Projection subtypes of rat neostriatal matrix cells revealed by intracellular injection of biocytin. J Neurosci 10:3421-3438.

Landry P, Wilson CJ, Kitai ST (1984) Morphological and electrophysiological characteristics of pyramidal tract neurons in the rat. Exp Brain Res 57:177-190.

Lei WL, Deng YP, Laverghetta AV, Reiner A (2004) Thalamic input to striatonigral and striatopallidal projection neurons in rats. Soc Neurosci Abstr, in press.

Le Moine C, Bloch B (1995) D1 and D2 dopamine receptor gene expression in the rat striatum: sensitive cRNA probes demonstrate prominent segregation of D1 and D2 mRNAs in distinct neuronal populations of the dorsal and ventral striatum. J Comp Neurol 355:418-426.

Lester J, Fink S, Aronin N, DiFiglia M (1993) Colocalization of D1 and D2 dopamine receptor mRNAs in striatal neurons. Brain Res 621:106-110.

Levesque M, Parent A (1998) Axonal arborization of corticostriatal and corticothalamic fibers arising from prelimbic cortex in the rat. Cereb Cortex 8:602-613

Levesque M, Charara A, Gagnon S, Parent A, Descenes M (1996a) Corticostriatal projections from layer $\mathrm{V}$ cells in rat are collaterals of long-range corticofugal axons. Brain Res 709:311-315.

Levesque M, Gagnon S, Parent A, Descenes M (1996b) Axonal arborizations of corticostriatal and corticothalamic fibers arising from the second somatosensory area in the rat. Cereb Cortex 6:759-770.

Marsden CD, Obeso JA (1994) The functions of the basal ganglia and the paradox of stereotaxic surgery in Parkinson's disease. Brain 117:877-897.

Miller R (1975) Distribution and properties of commissural and other neurons in cat sensorimotor cortex. J Comp Neurol 164:361-374.

Mink JW (1996) The basal ganglia: focused selection and inhibition of competing motor programs. Prog Neurobiol 50:381-425.

Oka H, Jinnai K (1978) Common projection of the motor cortex to the caudate nucleus and the cerebellum. Exp Brain Res 31:31-42.

Parent A, Smith Y, Filion M, Dumas J (1989) Distinct afferents to the internal and external pallidal segments in the squirrel monkey. Neurosci Lett 96:140-144.

Parent A, Charara A, Pinault D (1995) Single striatofugal axons arborizing in both pallidal segments and in the substantia nigra in primates. Brain Res 698:280-284.

Parthasarathy HB, Graybiel AM (1997) Cortically driven immediate early gene expression reflects modular influence of sensorimotor cortex on identified striatal neurons in the squirrel monkey. J Neurosci 17:2477-2491.

Paxinos G, Watson C (1998) The rat brain in stereotaxic coordinates, Ed 4. New York: Academic.

Reiner A, Anderson KD (1990) The patterns of neurotransmitter and neuropeptide co-occurrence among striatal projection neurons: conclusions based on recent findings. Brain Res Brain Res Rev 15:251-265.
Reiner A, Veenman CL, Medina L, Jiao Y, Del Mar N, Honig MG (2000) Pathway tracing using biotinylated dextran amines. J Neurosci Methods 103:23-37.

Reiner A, Jiao Y, Del Mar N, Laverghetta AV, Lei WL (2003) Differential morphology of pyramidal-tract type and intratelencephalicallyprojecting type corticostriatal neurons and their intrastriatal terminals in rats. J Comp Neurol 457:420-440.

Sadikot AF, Parent A, Smith Y, Bolam JP (1992) Efferent connections of the centromedian and parafascicular thalamic nuclei in the squirrel monkey: a light and electron microscopic study of the thalamostriatal projection in relation to striatal heterogeneity. J Comp Neurol 320:228-242.

Sidibe M, Smith Y (1996) Differential synaptic innervation of striatofucal neurones projecting to the internal or external segments of the globus pallidus by thalamic afferents in the squirrel monkey. J Comp Neurol 365:445-465.

Sulzer D, Pothos EN (2000) Regulation of quantal size by presynaptic mechanisms. Rev Neurosci 11:159-212.

Surmeier DJ, Reiner A, Ariano MA, Levine MS (1993) Are neostriatal dopamine receptors co-localized? Trends Neurosci 16:299-305.

Surmeier DJ, Song WJ, Yan Z (1996) Coordinated expression of dopamine receptors in neostriatal medium spiny neurons. J Neurosci 16:6579-6591.

Topni N, Buchs PA, Nikonenko I, Povilaitite P, Parisi L, Muller D (2001) Remodeling of synaptic membranes after induction of long-term potentiation. J Neurosci 21:6245-6251.

Turner RS, DeLong MR (2000) Corticostriatal activity in primary motor cortex of the macaque. J Neurosci 20:7096-7108.

Uhl GR, Navia B, Douglas J (1988) Differential expression of PPE and preprodynorphin mRNAs in striatal neurons: high levels of PPE expression depend on cerebral cortical afferents. J Neurosci 8:4755-4764.

Wang H, Pickel VM (2002) Dopamine D2 receptors are present in prefrontal cortical afferents and their targets in patches of the rat caudateputamen nucleus. J Comp Neurol 442:392-404.

Wang HB, Foehring R, Deng YP, Sun Z, Yamamoto K, Reiner A (2002) Single-cell RT-PCR and in situ hybridization histochemistry (ISHH) of substance $\mathrm{P}(\mathrm{SP})$ and enkephalin (ENK) co-occurrence in striatal projection neurons in rats. Soc Neurosci Abstr 28:359.15.

Waszczak BL, Martin LO, Greif GJ, Freedman JE (1998) Expression of a dopamine $\mathrm{D} 2$ receptor-activated $\mathrm{K}+$ channel on identified striatopallidal and striatonigral neurons. Proc Natl Acad Sci USA 95:11440-11444.

Wilson CJ (1987) Morphology and synaptic connections of crossed corticostriatal neurons in the rat. J Comp Neurol 263:567-580.

Wilson CJ (1992) Dendritic morphology, inward rectification and the functional properties of neostriatal neurons. In: Single neuron computation (McKenna T, J Davis, Kornetzer SF, eds), pp 141-171. San Diego: Academic.

Wilson CJ, Groves PM, Kitai ST, Linder JC (1983) Three-dimensional structure of dendritic spines in the rat neostriatum. J Neurosci 3:383-398.

Wouterlood FG, Pattiselanno A, Jorritsm-Byham B, Arts MPM, Meredith GE (1993) Connectional, immunocytochemical and ultrastructural characterization of neurons injected intracellularly in fixed brain tissue. In: Morphological investigations of single neurons in vitro (Meredith GE, Arbuthnott GW, eds), pp 47-169. New York: Wiley.

Wright AK, Norrie L, Ingham CA, Hutton AM, Arbuthnott GW (1999) Double anterograde tracing of the outputs from adjacent "barrel columns" of rat somatosensory cortex neostriatal projection patterns and terminal ultrastructure. Neuroscience 88:119-133.

Wright AK, Ramanthan S, Arbuthnott GW (2001) Identification of the source of the bilateral projection system from cortex to somatosensory neostriatum and an exploration of its physiological actions. Neuroscience 103:87-96.

Wu Y, Richard S, Parent A (2000) The organization of the striatal output system: a single-cell juxtacellular labeling study in the rat. Neurosci Res 38:49-62.

Zemanick MC, Strick PL, Dix RD (1991) Direction of transneuronal transport of herpes simplex virus 1 in the primate motor system is straindependent. Proc Natl Acad Sci USA 88:8048-8051. 